\title{
663715 DP - 1182
}

\section{A COMPUTER PROGRAM FOR CIRCULATION AND CONTROL OF LIBRARY JOURNALS}

M. S. FELDMAN

AND J. H. MADDOX

SRL

RECORD COPY

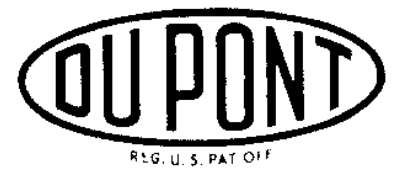

Savannah River Laboratory

Aiken, South Carolina 


\section{LEGAL NOTICE}

This report was prepered as en sccount of Goverament aponsored work. Nelther the Unitod States, nor the Commisetion, nor any portob acting on bethelf of the Cotomieston:

A. Makes cry warranty or representatlon, expreseded or Impiled, whlh respect to the accuof any Informatlon, epperatus, mothod, or procass dieclosed in thle report may not infriage privalojy owned ristate; or

B. Assumes any linbulities with reapect to the une of, or for damazes resulting from the

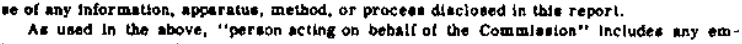
pioyes or contractor of the Commisention, or employee of such coniractor, to the extent that auch employee or contractor of the Commiesion, or enployee of auch contractor preperes. disteritnates, or providea Access to, any intormalion pursulant to his employment or contract with the commisetion, or his omployment with auch contractor.

Printed in the United States of America Available from

Clearinghouse for Federal Scientific and Technical Information National Bureau of Standards, U. S. Department of Commerce Springfield, Virginia 22151

Price: Printed Copy $\$ 3.00$; Microfiche $\$ 0.65$ 


\title{
663715
}

$\mathrm{DP}-1182$

Mathematics and Computers

(TID-4500)

\section{A COMPUTER PROGRAM FOR CIRCULATION AND CONTROL OF LIBRARY JOURNALS}

\author{
by \\ Myra S. Feldman \\ and \\ Judith H. Maddox
}

\begin{abstract}
Approved by
S. W. O'Rear, Supervisor

Technical Information Service

and

H. C. Honeck, Research Manager

Computer Applications Division
\end{abstract}

January 1969

E. 1. DU PONT DE NEMOURS \& COMPANY SAVANNAH RIVER LABORATORY

AIKEN, S. C. 29801

CONTRACT AT(07-2)-1 WITH THE

UNITED STATES ATOMIC ENERGY COMMISSION 


\begin{abstract}
A FORTRAN IV program (JURN), written for the IBM system $360 / 65$, automates the c1rculating and listing of journals in the technical library of the Savannah River Laboratory. The program provides circulation slips, renewal notices, and lists of circulating and reference coples of journals, in addition to complete information on holdings. The program is a revision of an earlier FORTRAN II program (DP-970).
\end{abstract}




\section{CONTENTS}

Page

Introduction . . . . . . . . . . . . . . 5

Capabilities of Program . . . . . . . . . . . . 7

Structure of Program . . . . . . . . . . . . 7

Maln Program . . . . . . . . . . . . . . 7

Subroutines . . . . . . . . . . . . . 9 9

Operating Procedures ... . . . . . . . . . 23

Input . . . . . . . . . . . . . . . . 23

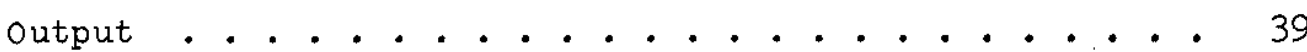

\section{LIST OF FIGURES}

Figure

1 General Flow Chart ............. 6

2 Flow Chart for JURN Program . . . . . . . 8

3 Flow Chart for Updating Master Library Tape . . . 10

4 Flow Chart for Subroutine CHANGE . . . . . . . . . II

5 Flow Chart for Subroutine TAPMAK . . . . . . 12

6 Data Sets ................ . . 13

7 Flow Chart for Subroutine PERSTP . . . . . . . 14

8 Flow Chart for Subroutine PERST1 . . . . . . 15

9 List of Journals Received by an Individual . . . . 16

10 List of Journals Circulated . . . . . . . . . 17

11 List of Reference Coples of Journals . . . . . . 18

12 Circulation SIlp . . . . . . . . . . . 19

13 List of Vendor Renewals . . . . . . . . . 20

14 List of Direct Order Renewals . . . . . . . . 21

15 List of Holdings . . . . . . . . . . . . 22

16 Personnel Card ................ 24

17 Perlodical Card . . . . . . . . . . . 25 
$\underline{\text { Page }}$

18 Direct Order Card . . . . . . . . . . 26

19 Information Cards . . . . . . . . . . 27

20 Distribution Card .............. 28

21 Journal Cards ................ 29

22. Arrangement of Input Cards . . . . . . . . 30

23 Master Control Card . . . . . . . . . . 32

24 Update Control card . . . . . . . . . . 33

25 Update Control Card for Deleting a Person ..... 34

26 Update Control Card for Deleting a Journal . . . . 34

27 Update Control Card for Deleting a Distribution List . . . . . . . . . . 35

28 Update Control Card for Changing Journal Data . . 35

29 Update Control Card for Changing a Distribution List .............. 36

30 Cards for Adding a Person . . . . . . . . 36

31 Cards for Adding a Distribution List . . . . . . 37

32 Cards for Changing Personnel Data . . . . . . 38

33 Update Control Card for Adding a Journal . . . . 39 


\section{INTRODUCTION}

Electronic data processing equipment is becoming widely used in many areas of information service. Computers can absorb much of the clerical load and afford fast, accurate control of library materials. The Technical Library of the Savannah River Laboratory is using an IBM System $360 / 65$ to control journal circulation and reordering and to list the journal holdings. The FORTRAN IV program (JURN) is a modiflcation of an earlier FORTRAN II program written for the IBM 704 computer. ${ }^{1}$

The automation of journal procedures saves considerable time normally expended in repetitive paperwork by providing updated lists of all journals recelved in the library and the disposition of these journals. Printouts from the program provide:

- Clrculation slips for each journal

- Lists of all journals circulated and all reference coples

- Complete holdings information

- Renewal notices two months in advance of renewal date

Approximately 1000 journal titles are now controlled by the program.

The procedure for setting up JURN is quite simple. Each journal is assigned an arbitrary four-digit number. There are elght punched cards for each journal titie and one distribution card for each copy of that journal title. The distribution card contains the payroll numbers of individuals to whom that particular journal copy is circulated. This set of cards is called the "journal cards."

Another set of cards called "personnel cards" contains the payroll number, name, and location of individuals.

The journal cards and personnel cards are added to a master library tape, which is updated periodically. Printouts may be obtained on demand. Figure 1 shows a general flow chart.

\footnotetext{
$I_{M}$. W. Skelton and R. R. Haefner. A Computer Program for Circulation of Library Journals. USAEC Report DP-970, E. I. du Pont de Nemours \& Co., Savannah River Laboratory, A1ken, S. C. (1965).
} 


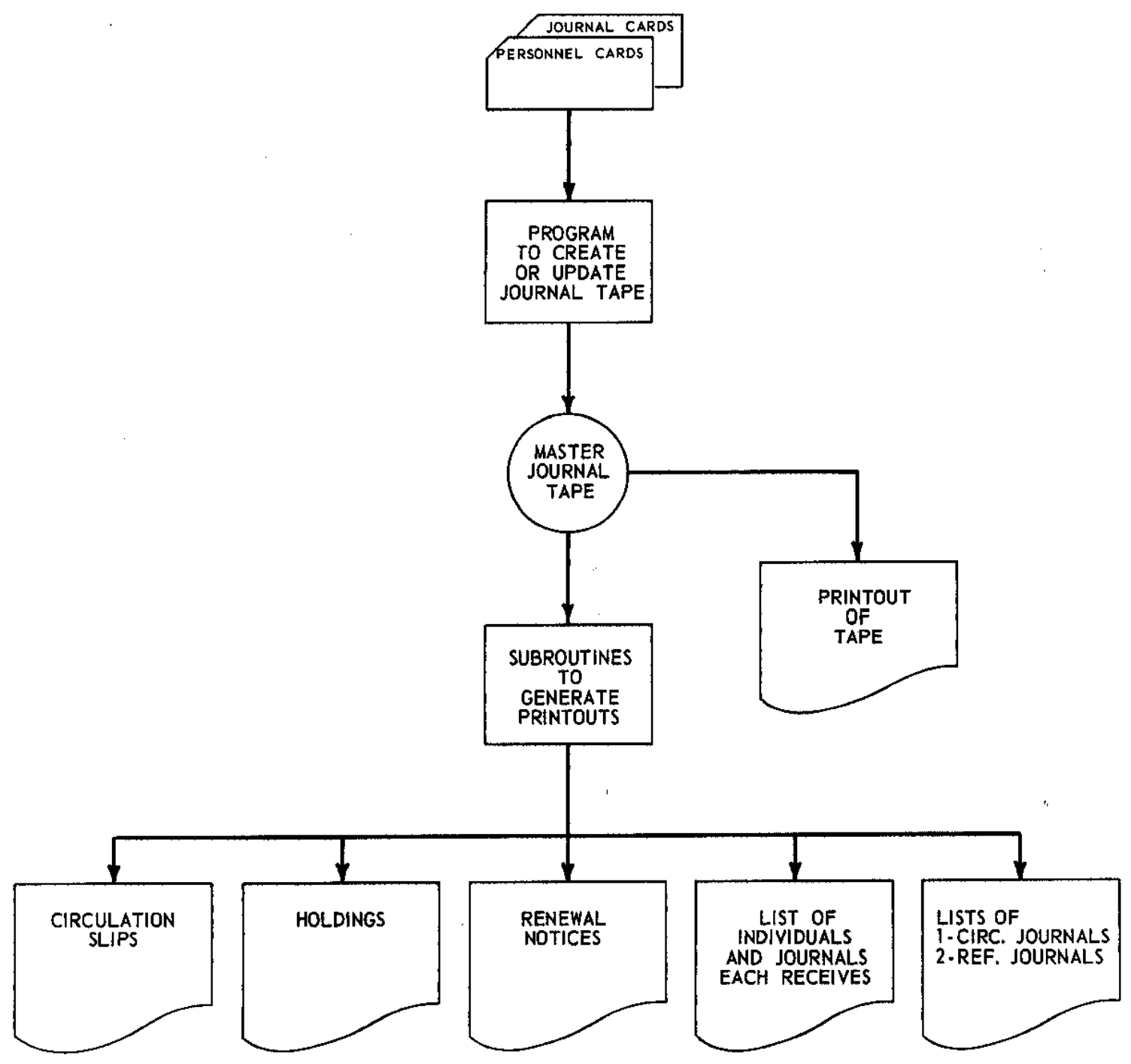

FIG. 1 GENERAL FLOW CHART 
The master tape need be made only once; thereafter, the tape is updated as changes are made. The decks of journal and personnel cards are maintained by library personnel and are used to get alphabetic and numeric lists of personnel and journal titles.

\section{CAPABILITIES OF PROGRAM}

The JURN program can accommodate 1499 people, 4000 journal titles, and 50 coples of each journal title. The index number for each person is his payroll number. Payroll numbers cannot exceed the number 9998, and the number 998 cannot be used. The index number for each journal is a random number that does not exceed the number 4000. Although 50 coples of a journal can be circulated, the circulation of each copy is restricted to 16 people.

The execution time for the program is approximately 30 minutes on an IBM System 360/65 computer when all list options are requested. The program occuples $250 \mathrm{~K}$ bytes of core space.

\section{STRUCTURE OF PROGRAM}

JURN has a main program and eleven subroutines; flve of these deal with output. The program has two main functions: to update the library tape and to produce a serles of edits. It can do either of these in one run but not both; thus, an updated library tape can be reviewed before the serles of edits are performed and the backup library tapes are modified.

\section{Main Program}

The main program reads in one master control card and calls for the subroutines as shown in the flow chart (F1gure 2 ). 


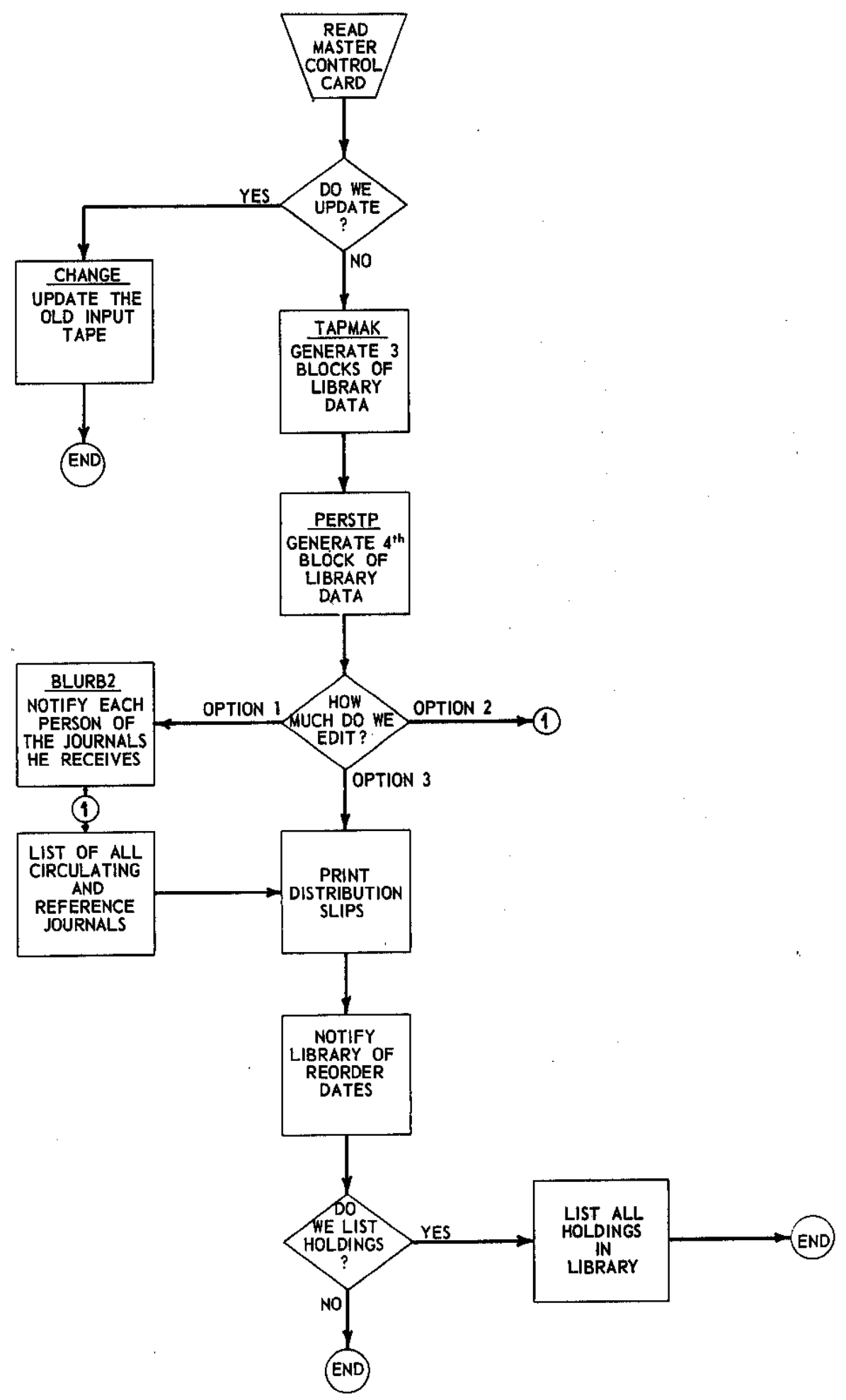

FIG. 2 FLOW CHART FOR JURN PROGRAM

-8 - 


\section{Subroutines}

CHANGE. This subroutine updates the existing library tape. Changes can be made in:

- Lists of personnel who receive journals

- Journal titles

- General information (i.e., information on holdings, t1tle changes, etc.)

- Distribution slips

A new library tape is made by combining the designated changes and the old tape (Figure 3 ).

The new library tape is automatically printed. The update control cards needed to accomplish these changes are described on pages 30-39. Figure 4 shows a flow chart for subroutine CHANGE.

SKIP. CHANGE calls SKIP when an update control card and its associated data cards are out of sequence. This subroutine then skips over the data cards and positions the input tape so CHANGE can read the next update control card.

TAPMAK. This subroutine reads the new, updated library tape and generates three sets of data, which are subsequently written in three separate temporary storage areas. The flrst data set includes the names and indices of all individuals receiving journals. The second set is a group of $n$ records, where $n$ is the total number of journals. Each journal information record contains the journal title, holdings information, and distribution data (indices of individuals receiving the journal). The third set of data is an alphabetic list of abbreviated journal titles. This set allows rapld accessing of journal names when no other data are desired.

A flow chart for the subroutine TAPMAK is shown in Figure 5, and a flow chart for the three data sets are shown in Figure 6.

PERSTP, PERST1, AND BLURB2. This series of subroutines generates a list of journals received by each individual.

PERSTP reads the journal information records developed by TAPMAK and converts the journal distributions into a list of indices of journals recelved by each person. It then writes one record per person in a temporary scratch area. Then, these records are arranged in order of ascending personnel indices (Figure 7). 
Since the personnel and journal indices are not assigned alphabetically, the records generated by PERSTP are not in alphabetic order. PERST1 (Figure 8 ) sorts the lists of fournals received by an individual into alphabetic order and includes the person's name instead of his index number.

BLURB2 then prints the list of journals received by each person (Figure 9).

SUBLST. Th1s subroutine provides a list of all circulating journals (Figure 10) and a list of all reference room journals (Figure 11).

PRLST. PRLST prints circulation lists for each journal as shown in Figure 12 .

SBORDR. A list of journals which must be renewed in 2 months is provided by SBORDR. One list is composed of journals which are ordered from a vendor (Figure 13). A second list contains journals to be ordered directly from the issuing agency and ineludes the agency's name and address (Figure 14).

BEURB1. This subroutine provides a list of journal holdings. The list contains journal titles, relevant comments (such as title changes), and volume data (Figure 15).

LIBUPD. LIBUPD automatically maintains two copies of the current Iibrary tape and one backup tape.

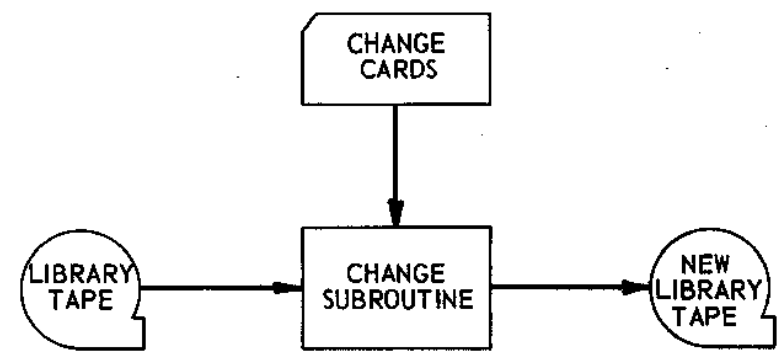

FIG. 3 FLOW CHART FOR UPDATING MASTER LIBRARY TAPE 


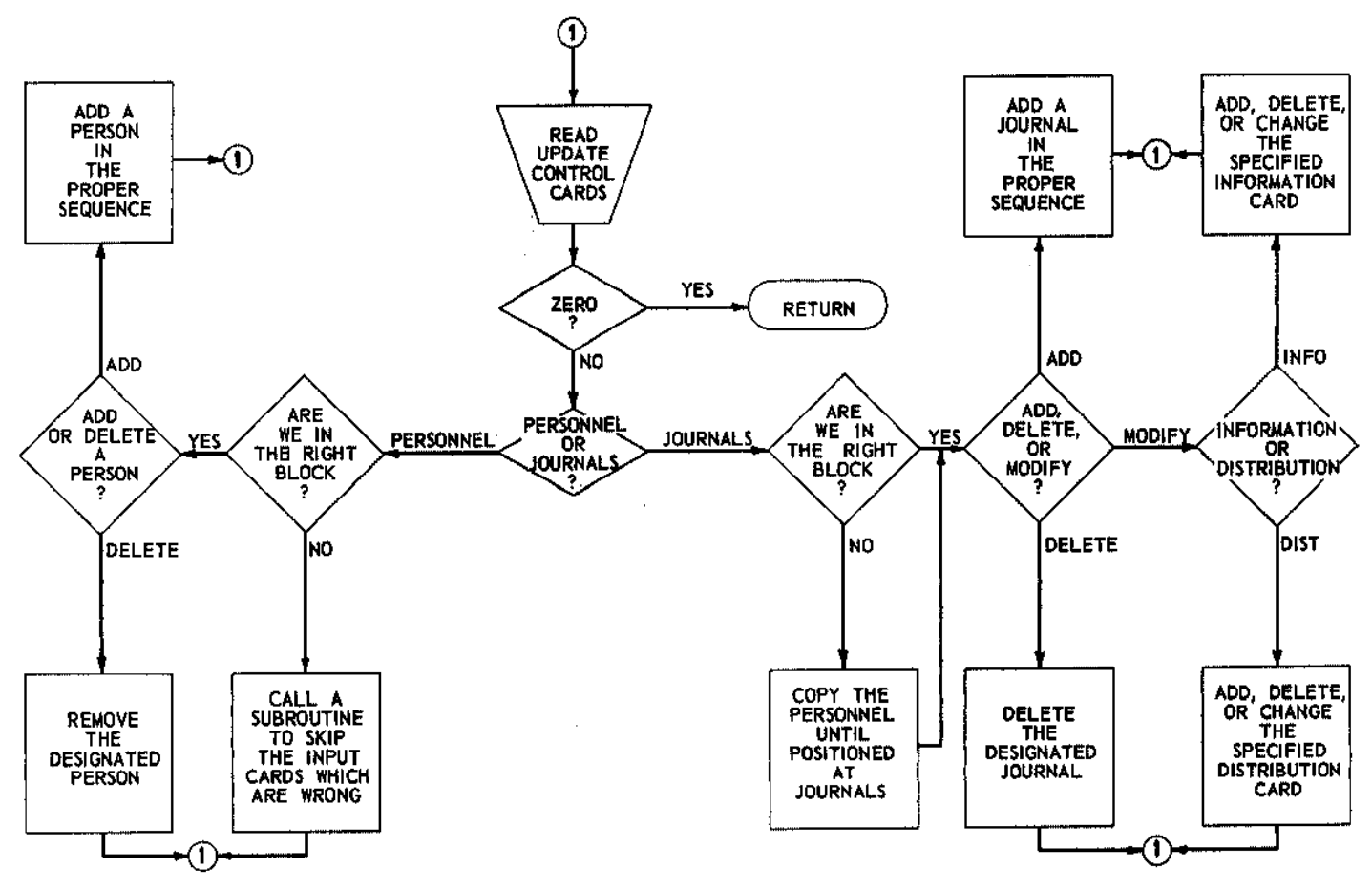
The progrom will:
1. Find the specified journat.
5. Rood over on itom, correct, and copy
B. Copy to and of joumal.
2. Find the specified card. the corroctad item for a chango.
9. Allow journals to be added at and
3. Insert on oddition of the proper place.
4. Read over an item without copying for
6. Read next control card. of tope.
7. Make subsequent changes to the 10. Copy the master tope if the changes
terminate before the master tope ends. same journal.

FIG. 4 FLOW CHART FOR SUBROUTINE CHANGE 


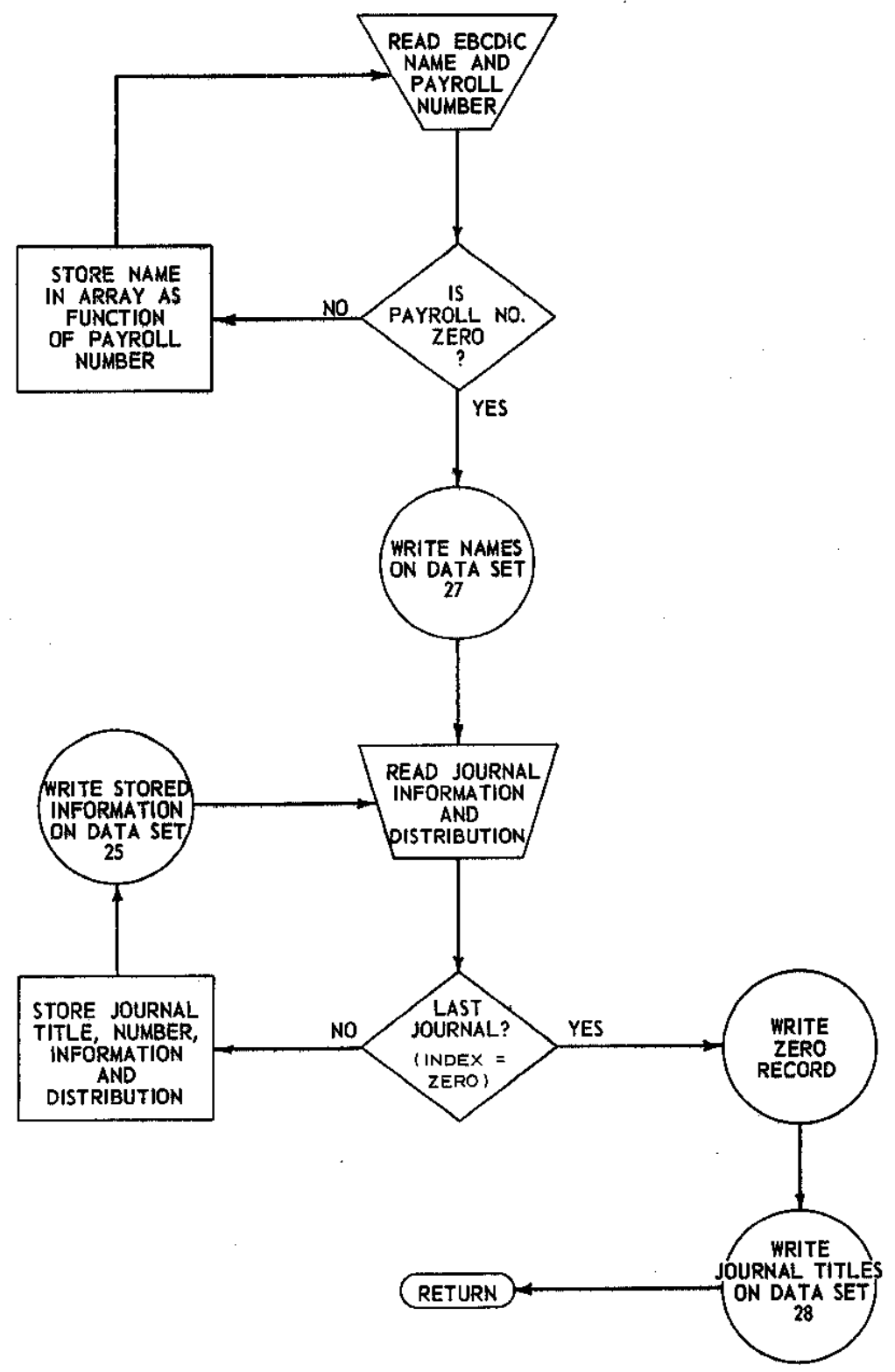

FIG. 5 FLOW CHART FOR SUBROUTINE TAPMAK 


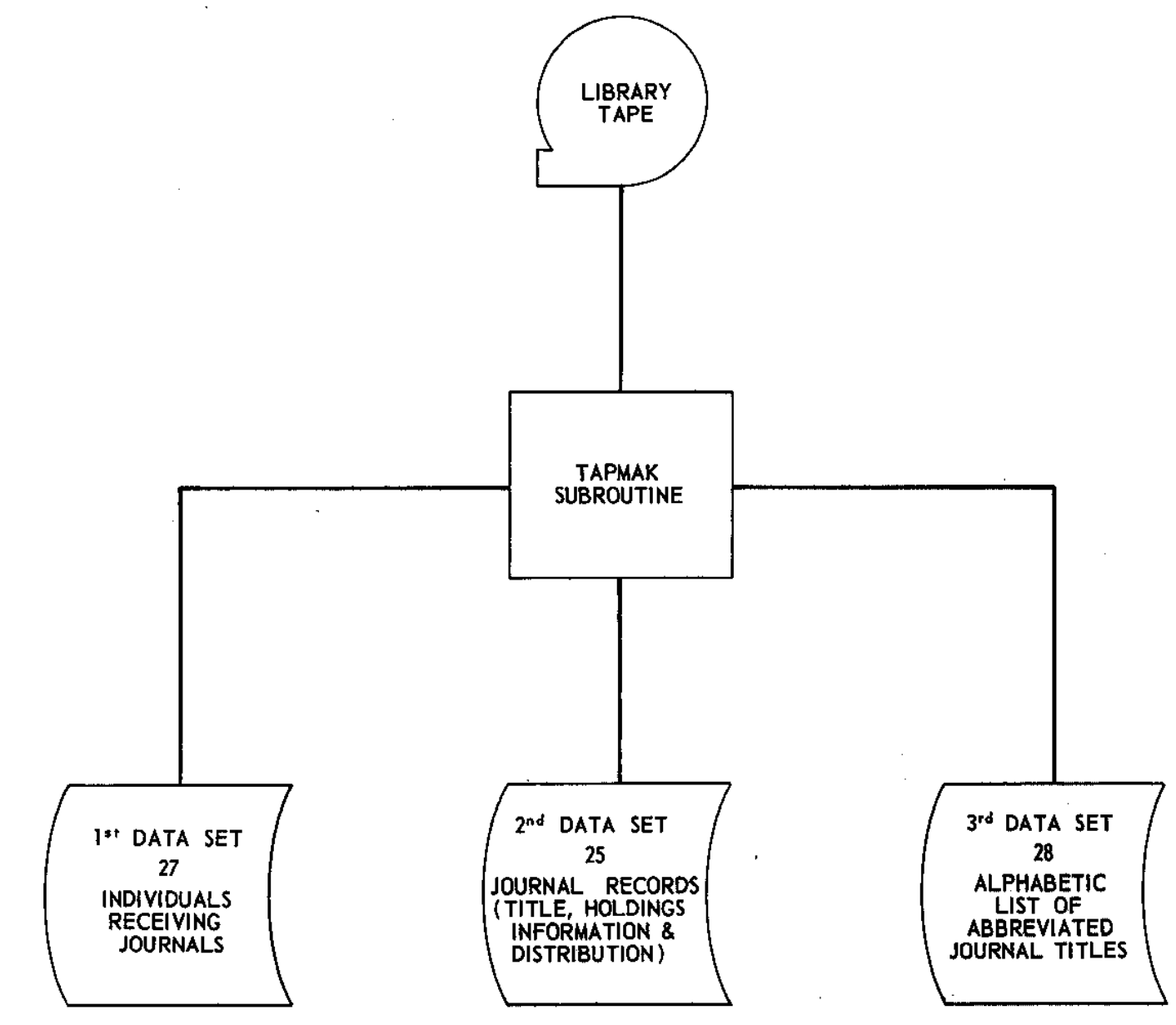

FIG. 6 DATA SETS 


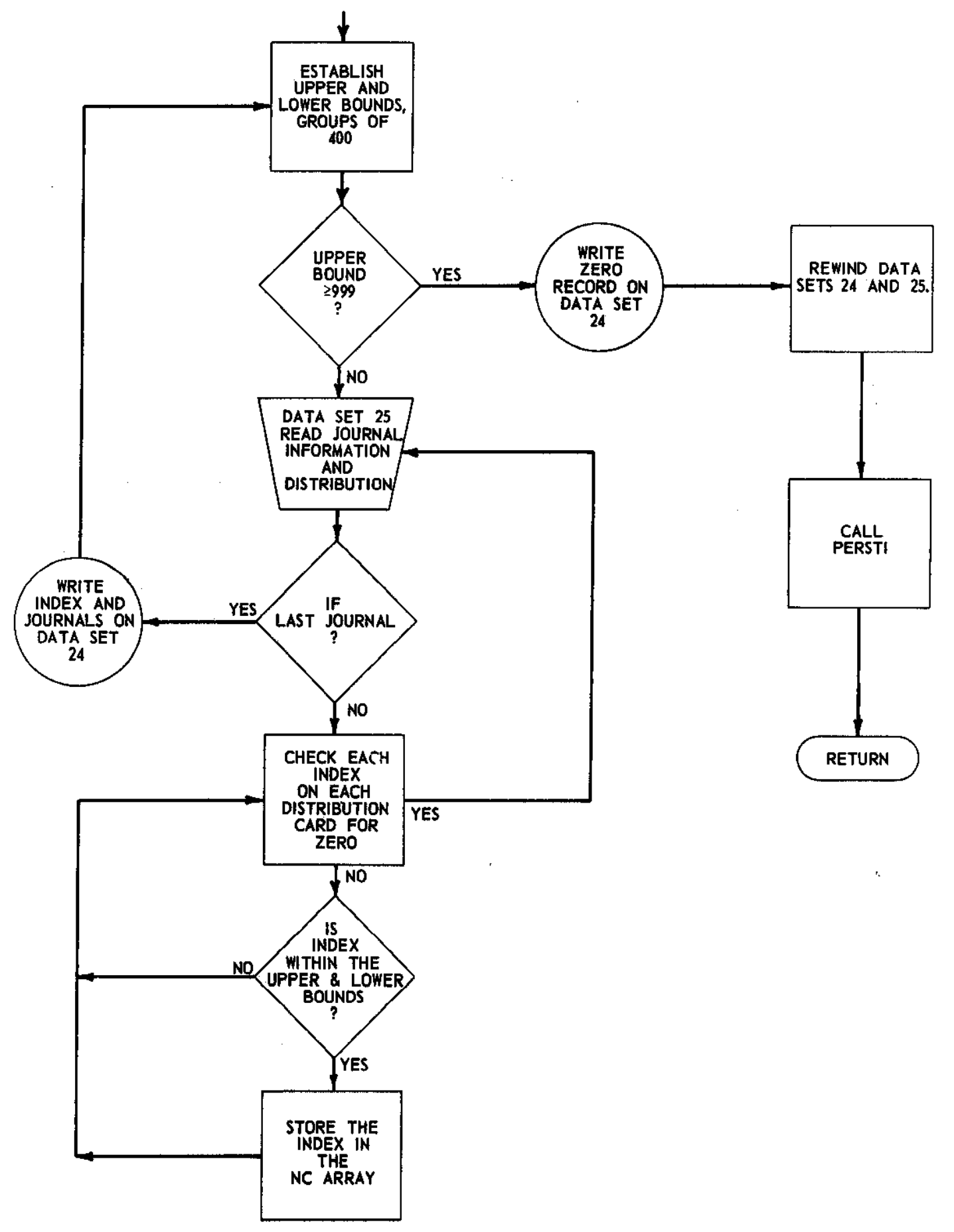

FIG. 7 FLOW CHART FOR SUBROUTINE PERSTP 


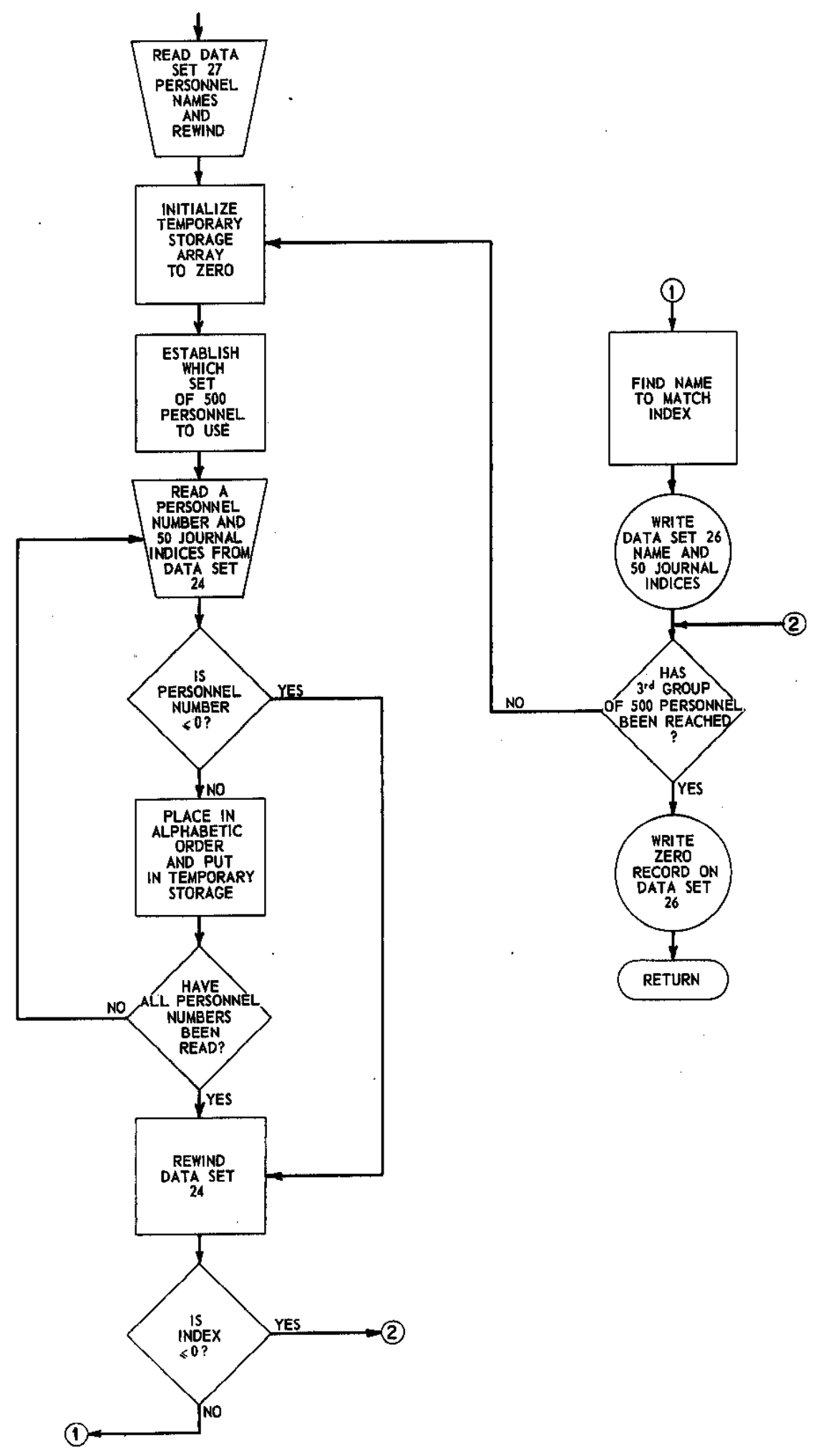

FIG. 8 FLOW CHART FOR SUBROUTINE PERSTI 
DESSAUER,G $773 \mathrm{~A}$

IHIS IS A LIST OF JOURNALS CIRCULATEDTOOYOU BY TISS, PLEASE INDICATE ANO RETURN TOOTIS.

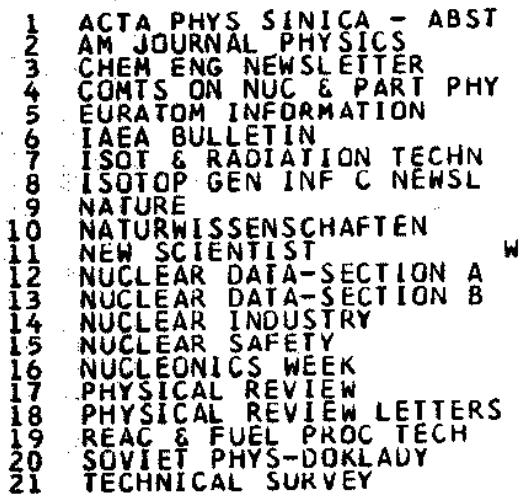

FIG. 9 LIST OF JOURNALS RECEIVED BY AN INDIVIDUAL

$-16-$ 


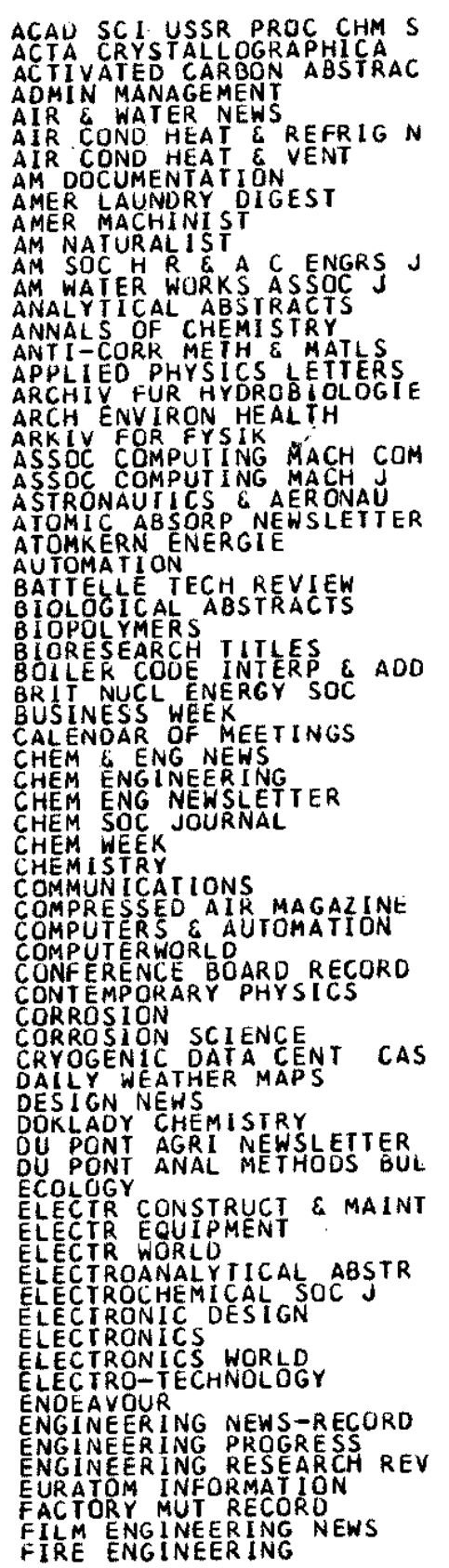

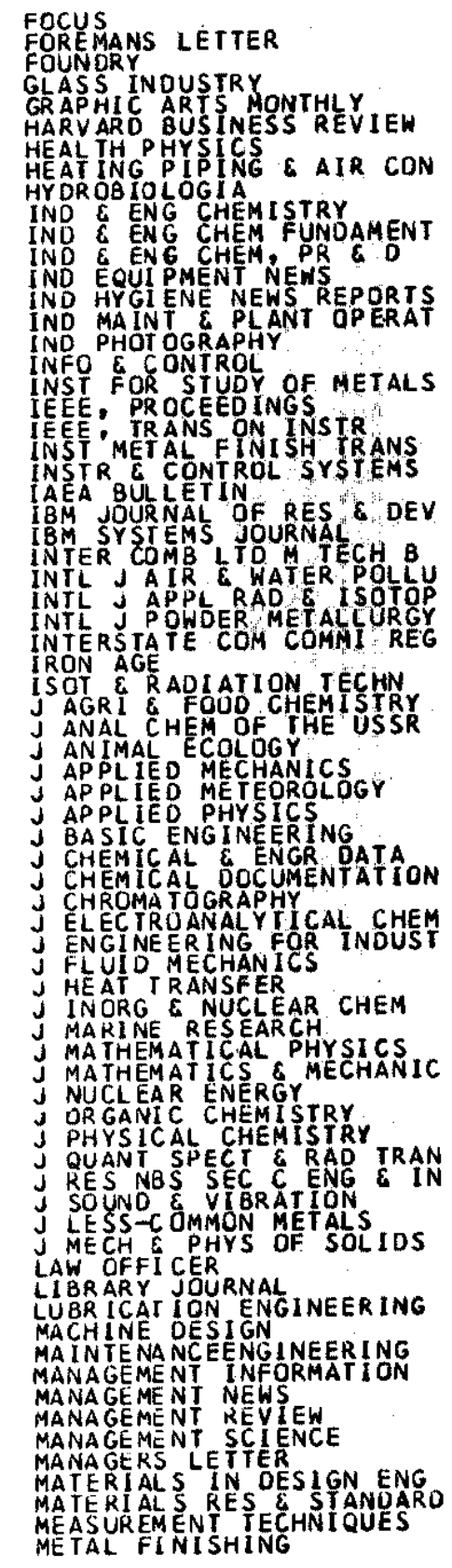

FIG. 10 LIST OF JOURNALS CIRCULATED 

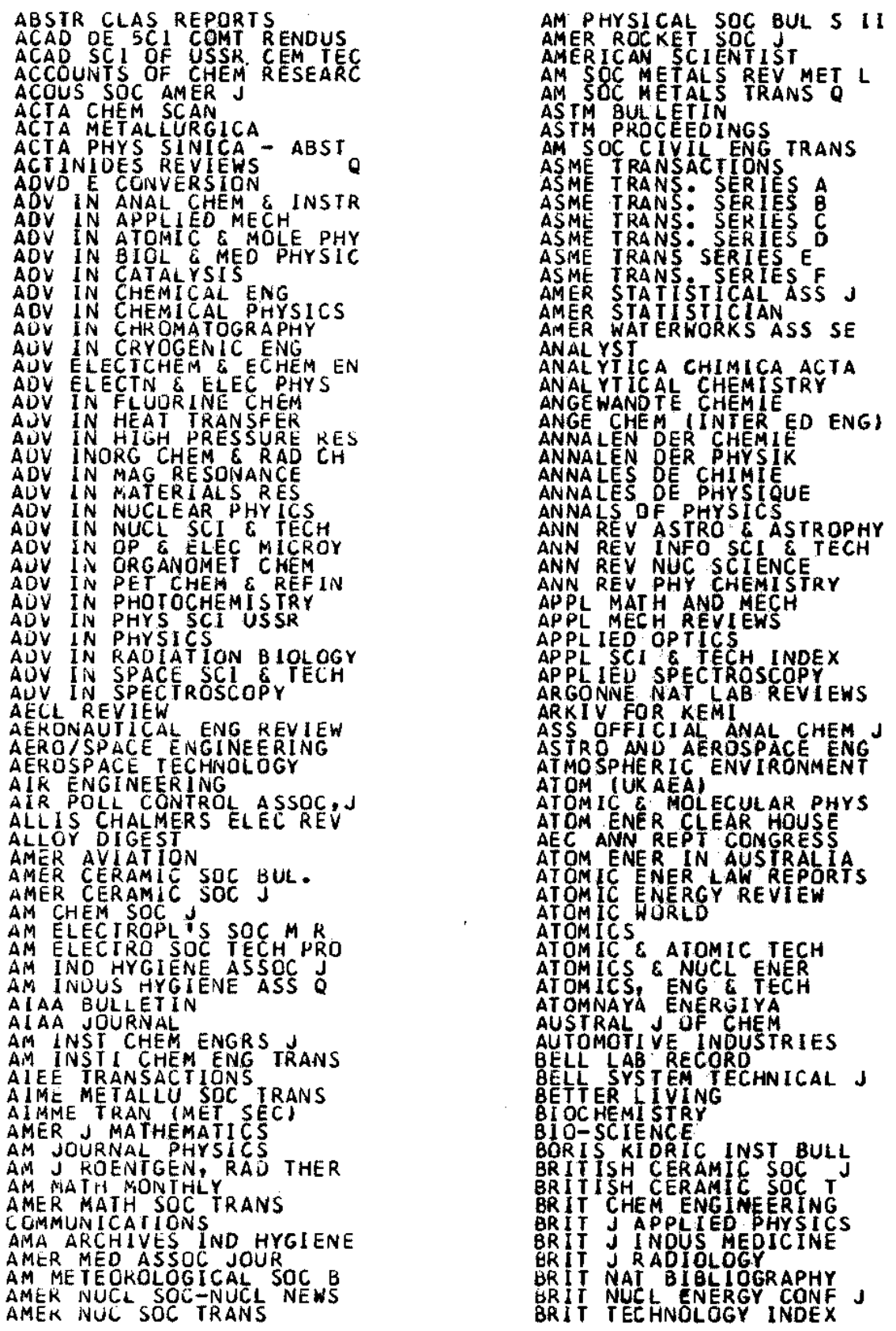

FIG. 11 LIST OF REFERENCE COPIES OF JOURNALS 


\begin{tabular}{|c|c|c|}
\hline \multicolumn{3}{|c|}{$\begin{array}{l}\text { NUCLEAR SCIENCE ABSTRACT } \\
\text { BLWEEKLY COPY } 2 \\
\text { PLEASE READ PROMPILY }\end{array}$} \\
\hline 1 & SIDDALL, TH & $773 A$ \\
\hline 2 & MILHAM,RC & $773 A$ \\
\hline 3 & KERRIGAN, WJ & $773 A$ \\
\hline 4 & $S C H W A B, C$ & $773 A$ \\
\hline 5 & CHURCH,JP & $773 A$ \\
\hline 6 & BROWN, DA & $773 A$ \\
\hline 7 & OVERMAN, RF & $773 A$ \\
\hline 8 & OWEN,JH & $773 \mathrm{~A}$ \\
\hline 9 & BAILEY,CE & $773 A$ \\
\hline 10 & RANDALL, D & 7734 \\
\hline 11 & HYOER, ML & $773 A$ \\
\hline 12 & LOWE,JT & $773 A$ \\
\hline 13 & BROWN, RJ & $773 A$ \\
\hline 14 & HARBOUR, RM & $773 A$ \\
\hline 15 & & \\
\hline 16 & TIS LIBRARY & 7734 \\
\hline
\end{tabular}

FIG. 12 CIRCULATION SLIP 
ORDER THE FOLLOWING JOURNALS BY THE LOTH MONTH OF THE YEAR ACADEMY OF SCIENCES USSR, PROCEEDINGS OF THE GHENISTRY SECTION ACTA CHEMICA SCANDINAVICA

ACTA CRYSTALLOGRAPHICA

ACTA METALLURGICA

ACTINIDES REVIEWS

ADMINISTRATIVE MANAGEMENT

ADVANCED ENERGY CONVERSION

AECL REVIEW

AEROSPACE TECHNOLOGY

AIR AND WATER NEWS

AIR CONDITIONING, HEATING \& REFRIGERATION NEWS

AIR CONDITIONING, HEATING AND VENTILATING

AIR POLLUTION CONTROL ASSOCIATION JOURNAL

ALLOY OIGEST

AMERICAN AVIATION

AMERICAN CERAMIC SOCIETY BULLETIN

AMERICAN CERAMIC SUCIETY JUURNAL

AMERICAN CHEMICAL SOCIETY JOURNAL

AMERICAN DOCUMENTATION

AMER ICAN INDUSTRIAL HYGIENE ASSOCIATION JOURNAL

FIG. 13 LIST OF VENDOR RENEWALS 


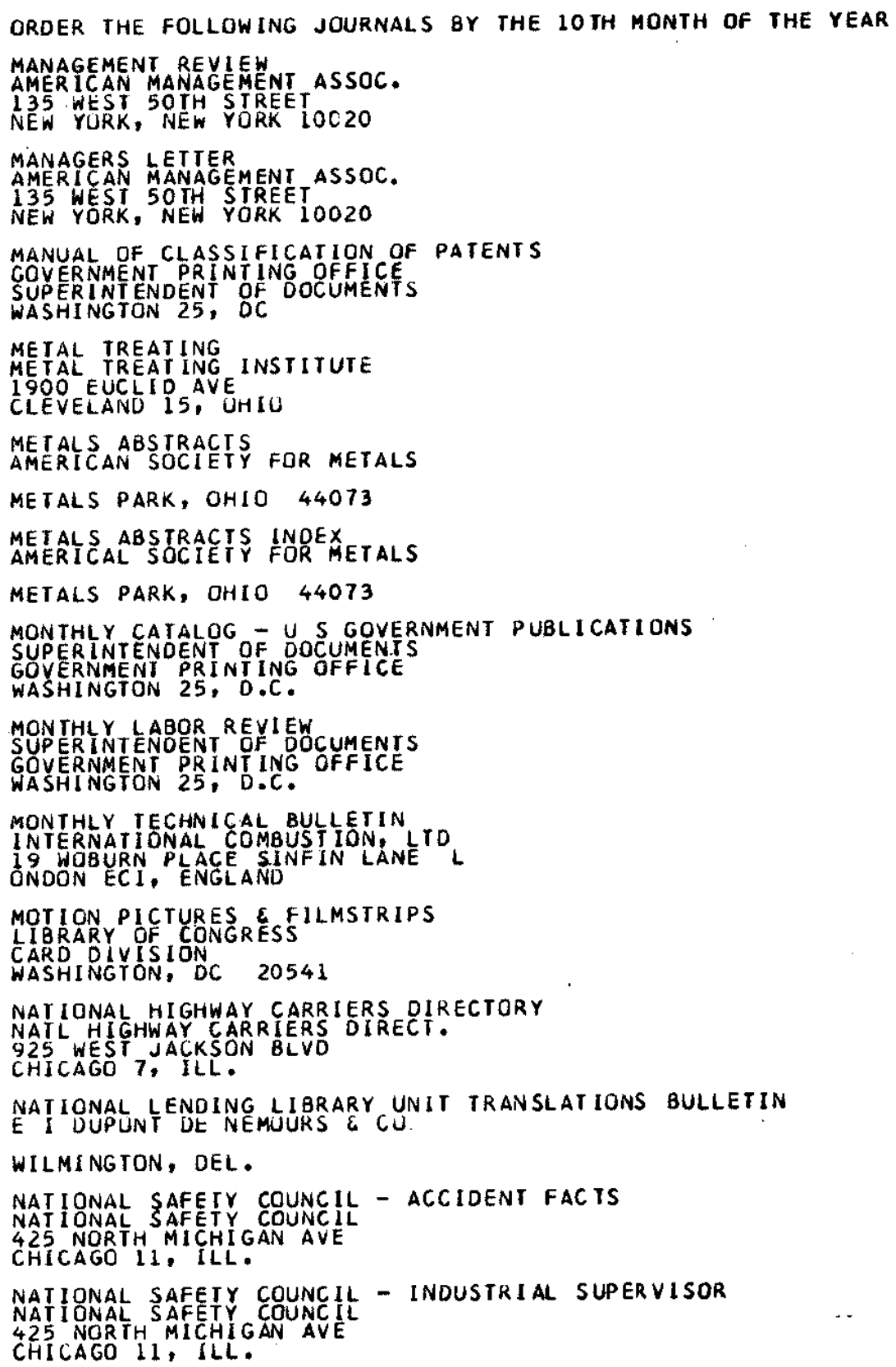

FIG. 14 LIST OF DIRECT ORDER RENEWALS 


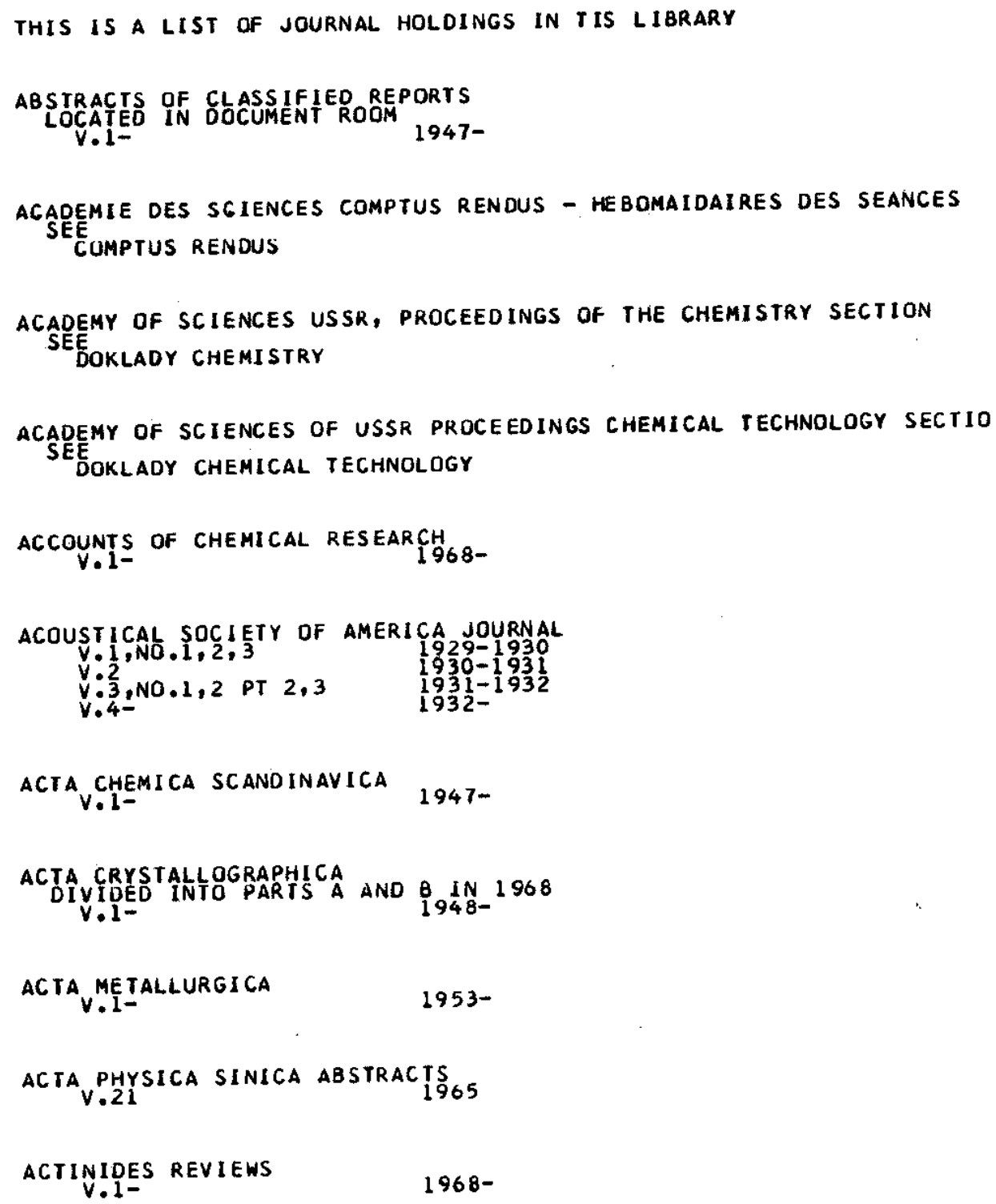

FIG. 15 LIST OF HOLDINGS 
OPERATING PROCEDURES

Input

Data Cards. Two types of cards are used for input to the library tape: personnel cards and journal cards. The format of the personnel cards is given in Figure 16.

There are four types of journal carảs for each journal title:

- Periodical card

- Direct order card

- Information cards

- Distribution card

Formats and examples of the journal cards are given in Figures $17-20$.

Each journal will have eight cards if ordered directly from the 1ssulng agency or seven cards if ordered from the vendor (Figure 2l). All of these cards must be submitted for every journal title.

The cards are arranged for original input to the program as shown in Figure 22. These cards are thereafter maintained by library personnel and updated manually. They can be used for alphabetic and numeric listings.

(Text continued on page 30 ) 


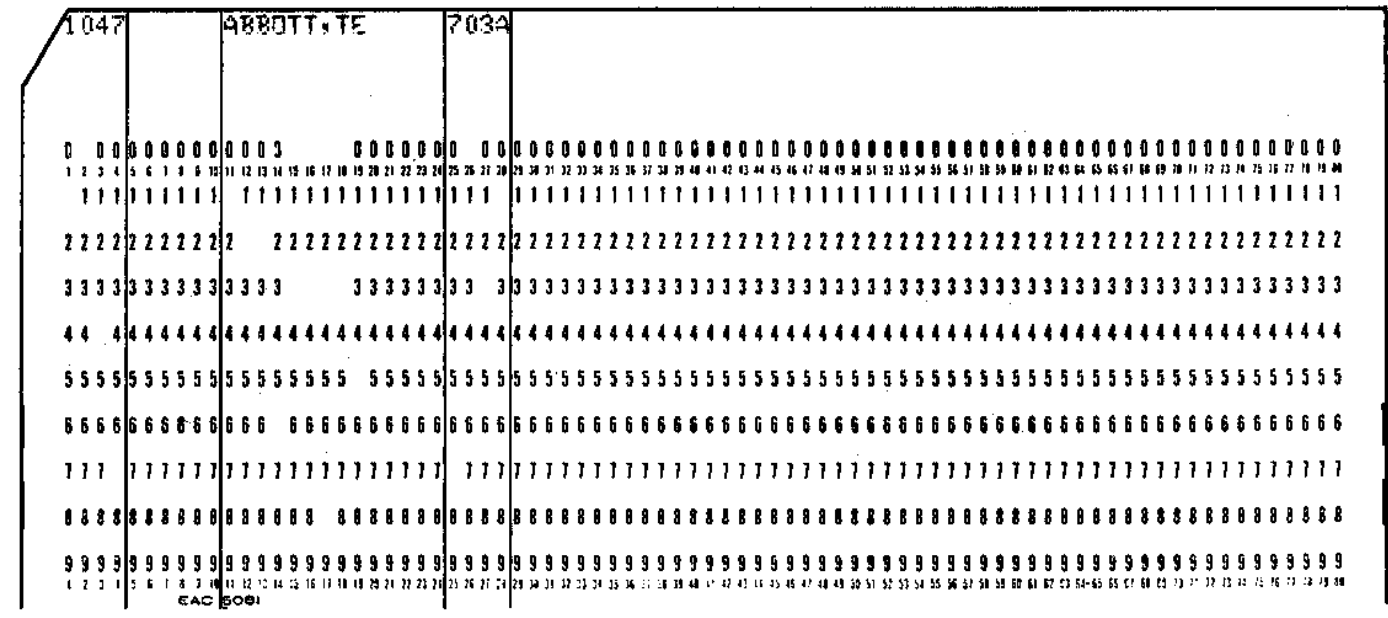

$\begin{aligned} \frac{\text { Column }}{1-4} & \begin{array}{l}\text { Individual's payroll number (right Justi- } \\ \text { fled) }\end{array} \\ 5-10 & \text { Blank } \\ 11-24 & \text { Name of Person } \\ 25-28 & \text { Location }\end{aligned}$

FIG. 16 PERSONNEL CARD 


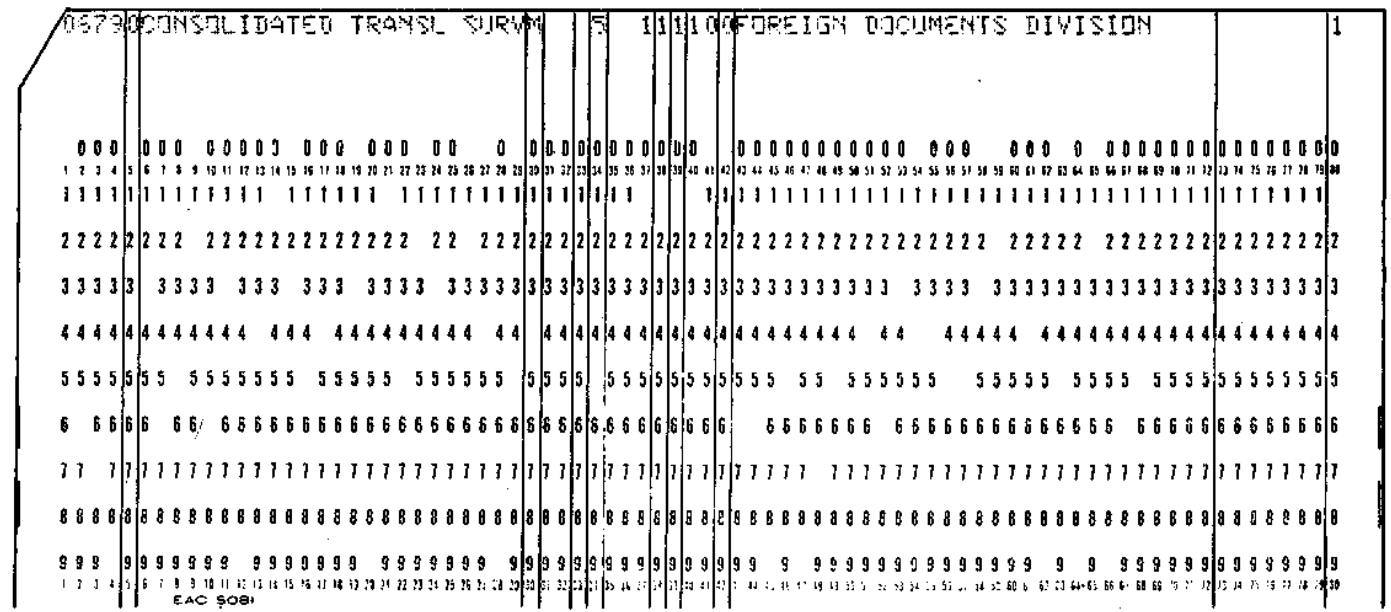

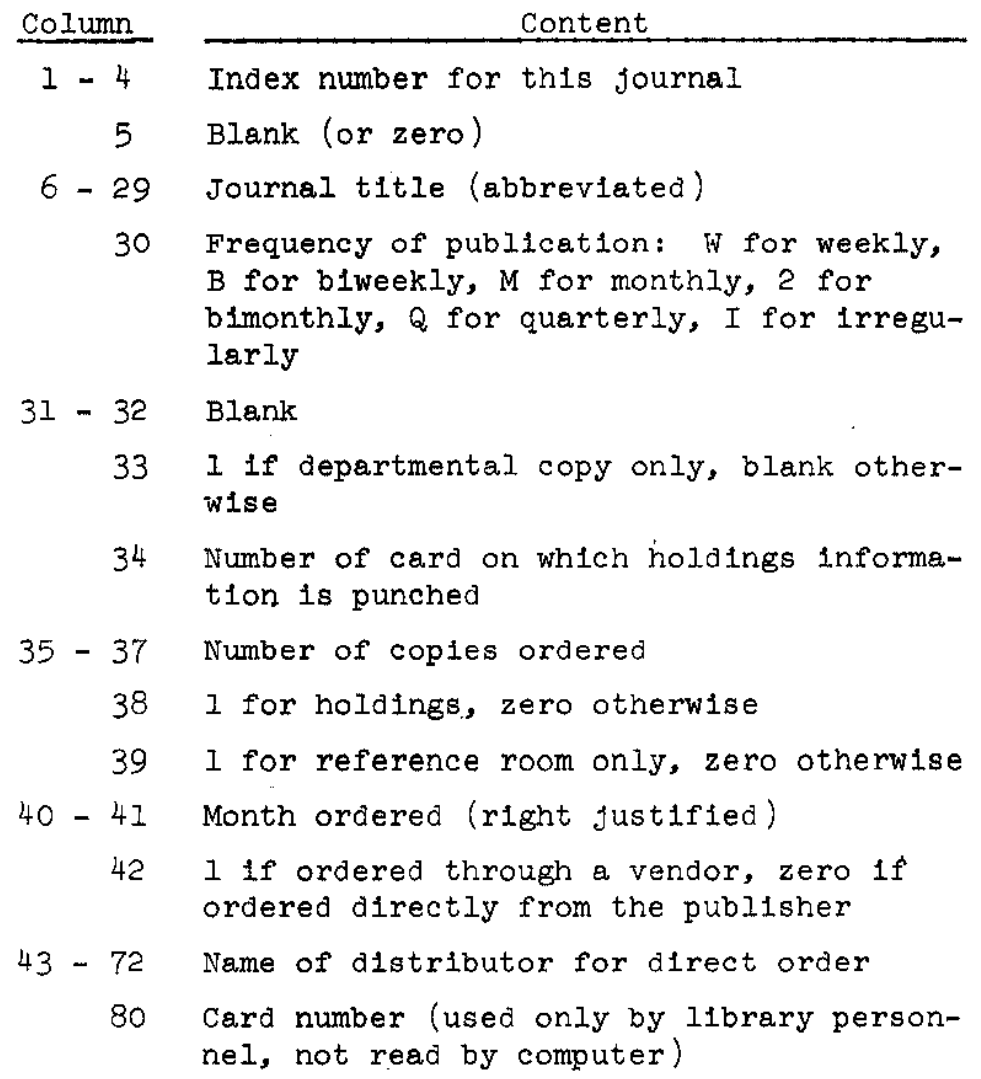

FIG. 17 PERIODICAL CARD 

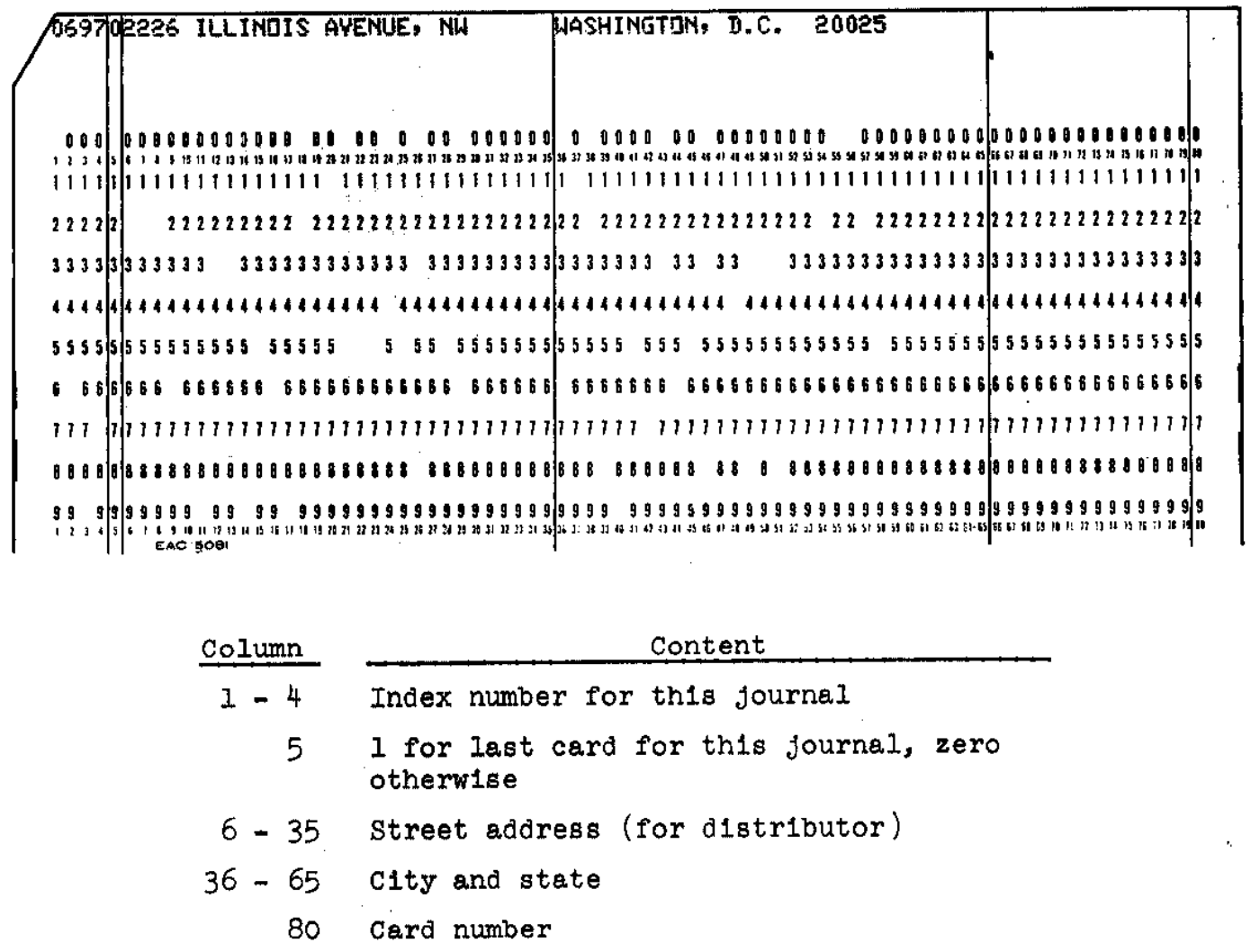

FIG. 18 DIRECT ORDER CARD 


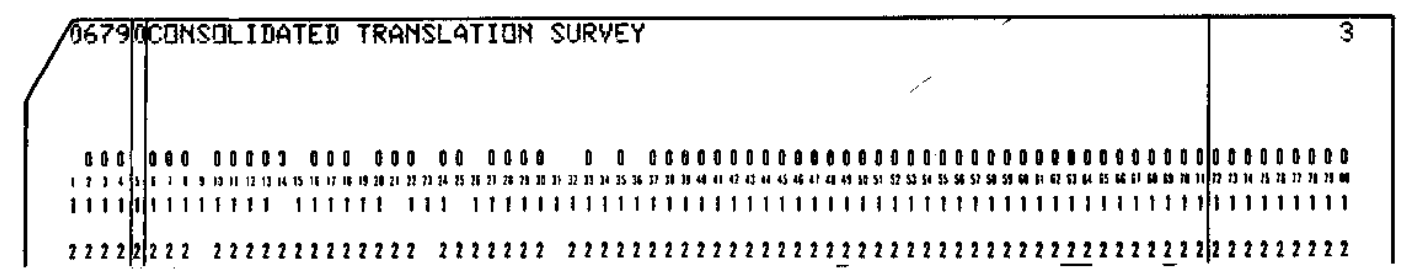

Information Card I (should always contain the unabbrevlated journal title)

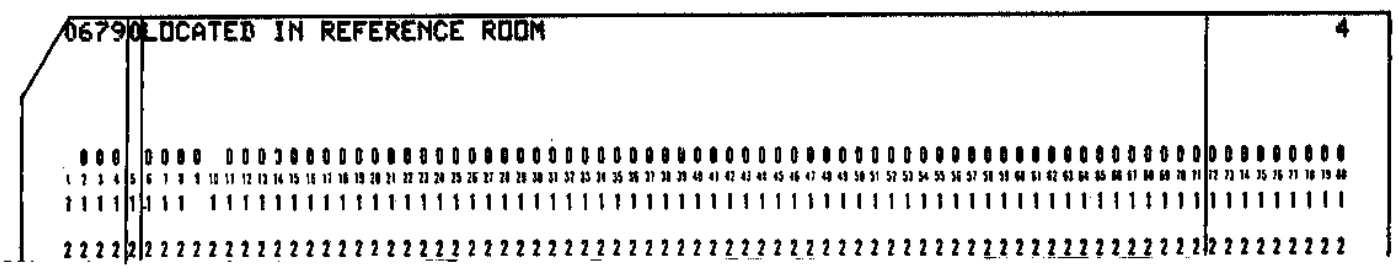

Information Card II (general information such as title changes)

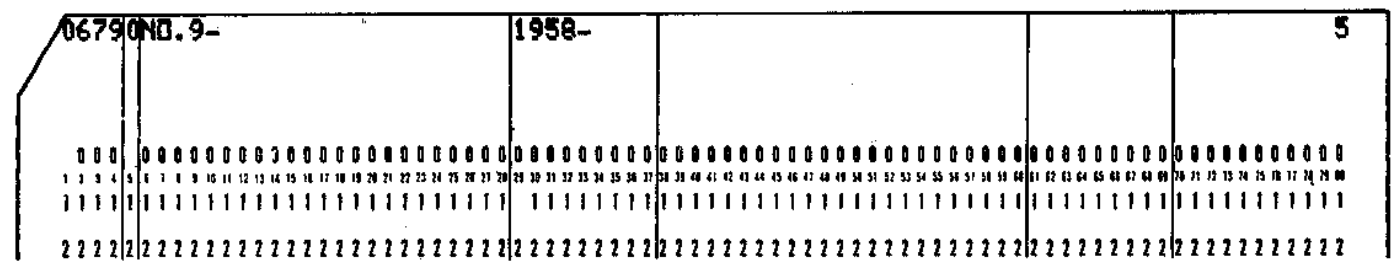

Information Cards III-VI (holdings information)

\begin{tabular}{|c|c|}
\hline Column & Content \\
\hline $\begin{array}{r}1-4 \\
5\end{array}$ & $\begin{array}{l}\text { Index number for this journal } \\
\text { I for last card for this journal, zero } \\
\text { otherwise }\end{array}$ \\
\hline \multirow[t]{5}{*}{$6-71$} & $\begin{array}{l}\text { General information such as title, title } \\
\text { changes, holdings information. Holdings } \\
\text { information should adhere to the following } \\
\text { format: }\end{array}$ \\
\hline & Content \\
\hline & Volume data \\
\hline & Beginning and ending year \\
\hline & Volume data \\
\hline & $61-69$ Beginning and ending year \\
\hline
\end{tabular}

\section{FIG. 19 INFORMATION CARDS}



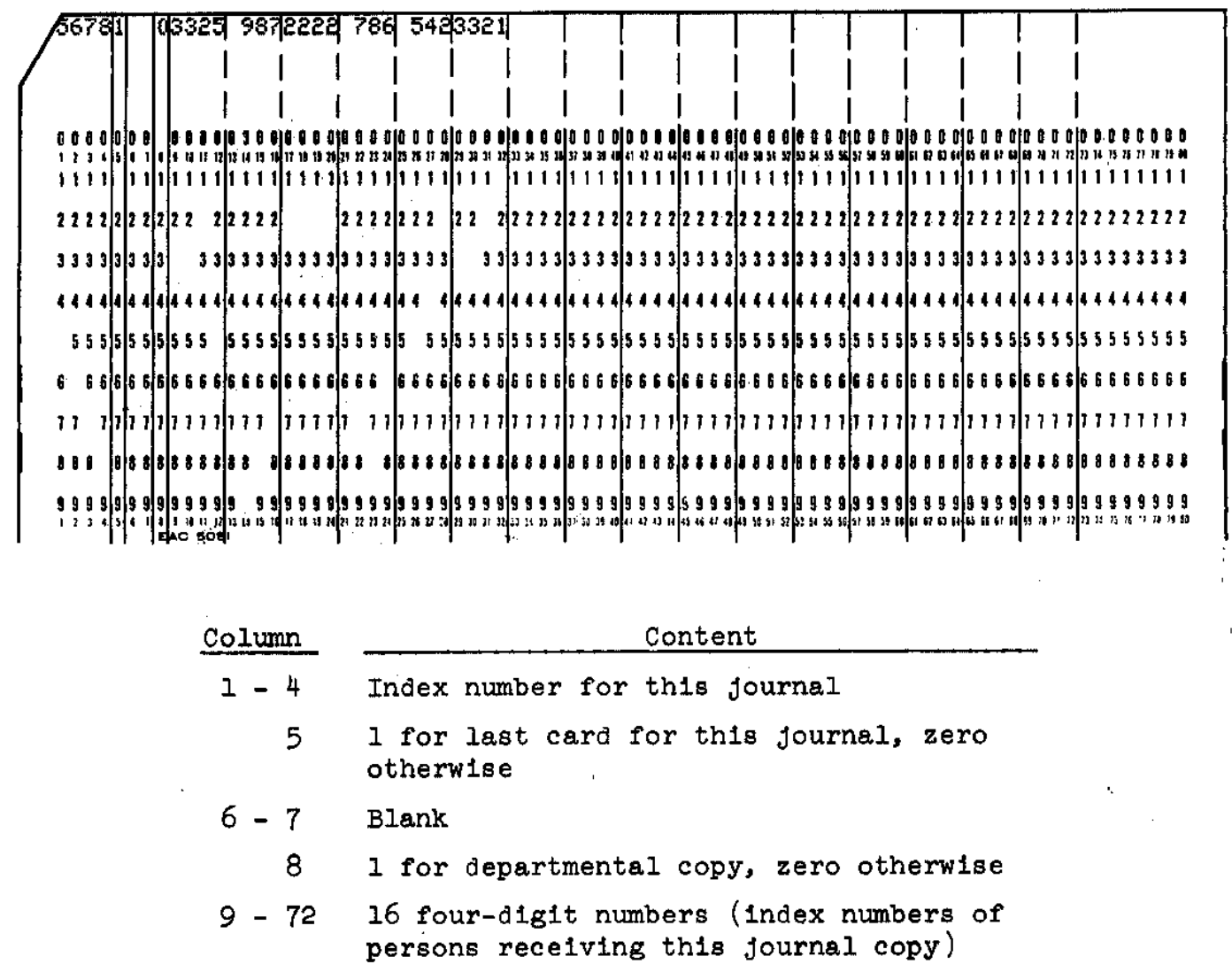

FIG. 20 DISTRIBUTION CARD 

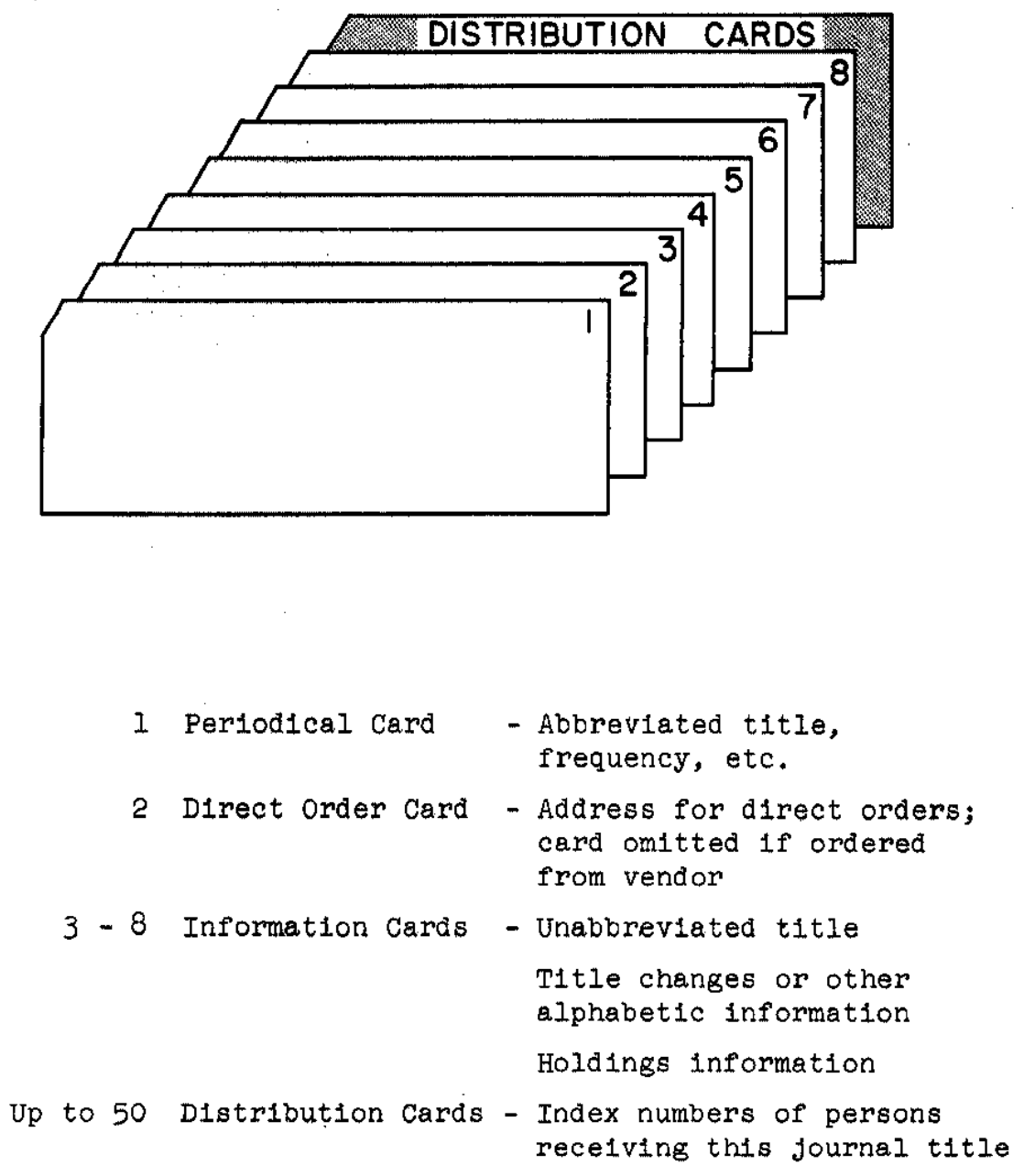

FIG. 21 JOURNAL CARDS 


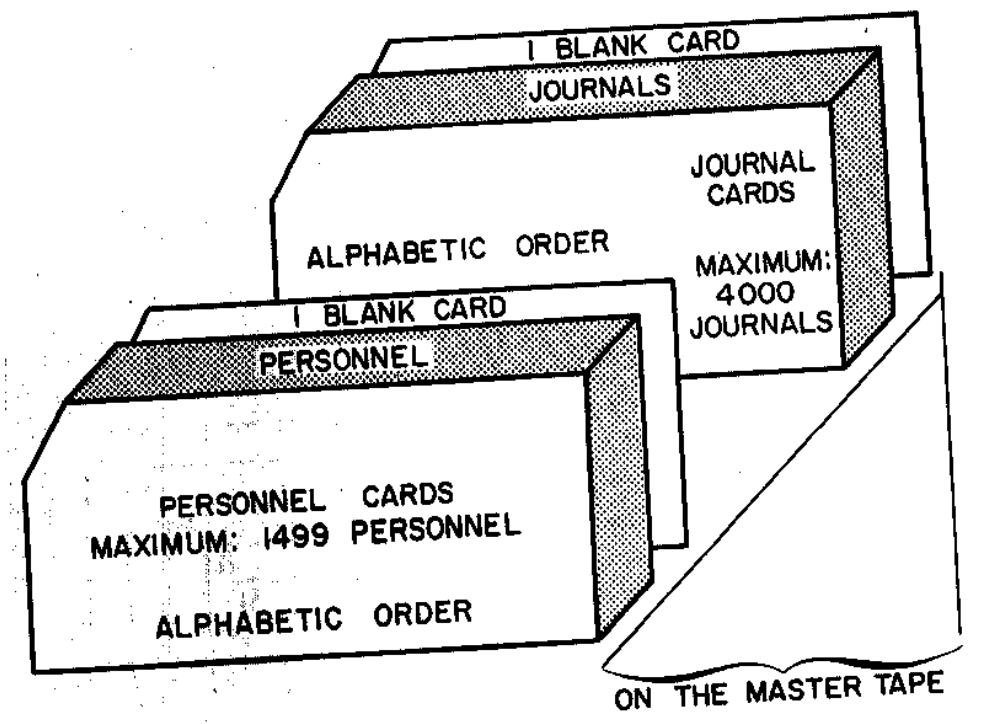

FIG. 22 ARRANGEMENT OF INPUT CARDS

Control Cards to Execute JURN Program. One master control card (Figure 23) should be the first card of input immediately followed by the changes. If no changes are to be made, this will be the only input card.

Nine procedures for updating the library tape are avallable, each slightly different from the others.

1. Add a name to the distribution list (alphabetic

2. Delete a name from the distribution list.

3. Change a name, number, or location for someone already on the distribution list.

4. Add a journal (alphabetic order).

5. Delete a journal.

6. Change journal data supplied on a periodical card, a direct order card, or any of the six information cards.

7. Add a distribution list.

8. Delete a distribution list.

9. Change a distribution list. 
Each of the nine procedures requires one update control card (Figure 24). Delete procedures require the update control card only (Figures 25, 26, and 27). Change procedures 6 and 9 above require the update control card plus the corrected card for replacement (Figures 28 and 29). The procedures for adding personnel or distribution lists require the update control card plus the addition card (Figures 30 and 31 ).

Changing the name, location, or number of a person requires two steps (Figure 32): (1) add the corrected data (one update control card plus the addition card), and (2) delete the old data (one update control card only).

The addition of a fournal requires an update control card plus the block of new journal cards (F1gure 33 ).

The input cards for changes must be set up as follows:

- Begin changes with a master control card.

- Change, add, or delete the personnel cards first and in the same sequence as the tape.

- Change, add, or delete journal cards in the same sequence as they appear on the tape.

- Within each journal block, make changes, additions, or deletions as they appear within the block. The prescribed order is: periodical card, direct order card, information cards, and distribution cards.

- End the change input deck with a blank card. 


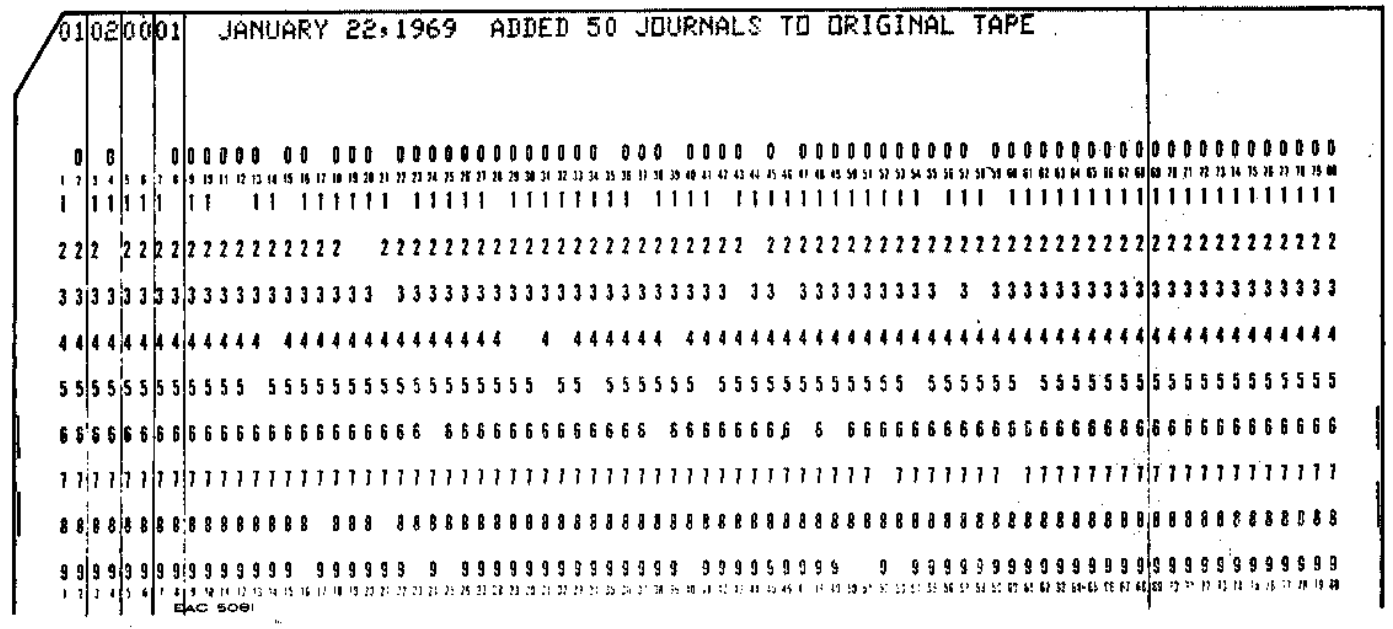

\begin{tabular}{|c|c|}
\hline Column & Content \\
\hline $1-2$ & $\begin{array}{l}\text { Ol if changes follow this card; zero } \\
\text { otherwise }\end{array}$ \\
\hline $3-4$ & $\begin{array}{l}\text { Output control card: } \\
00 \text { - clrculation lists and reorder } \\
\text { lists only } \\
01 \text { - list of circulating and refer- } \\
\text { ence room journals } \\
02 \text { - list of the journals each person } \\
\text { recelves }\end{array}$ \\
\hline $5-6$ & $\begin{array}{l}\text { Ol - list of library holdings; zero } \\
\text { otherwise }\end{array}$ \\
\hline $7-8$ & Month of this run \\
\hline $9-68$ & $\begin{array}{l}\text { Alphameric information (miscellaneous } \\
\text { data, not used by computer) }\end{array}$ \\
\hline
\end{tabular}

FIG. 23 MASTER CONTROL CARD 

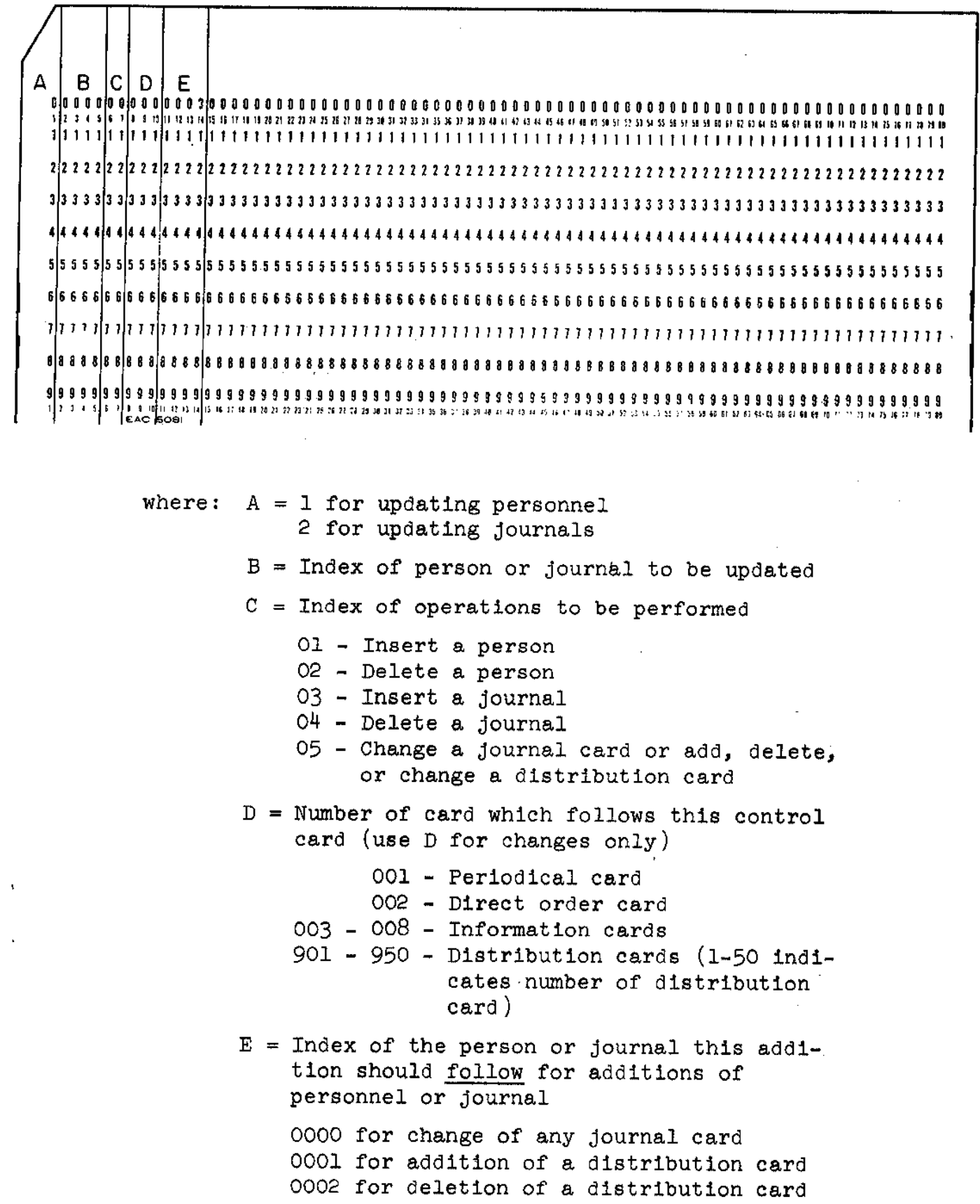

FIG. 24 UPDATE CONTROL CARD 


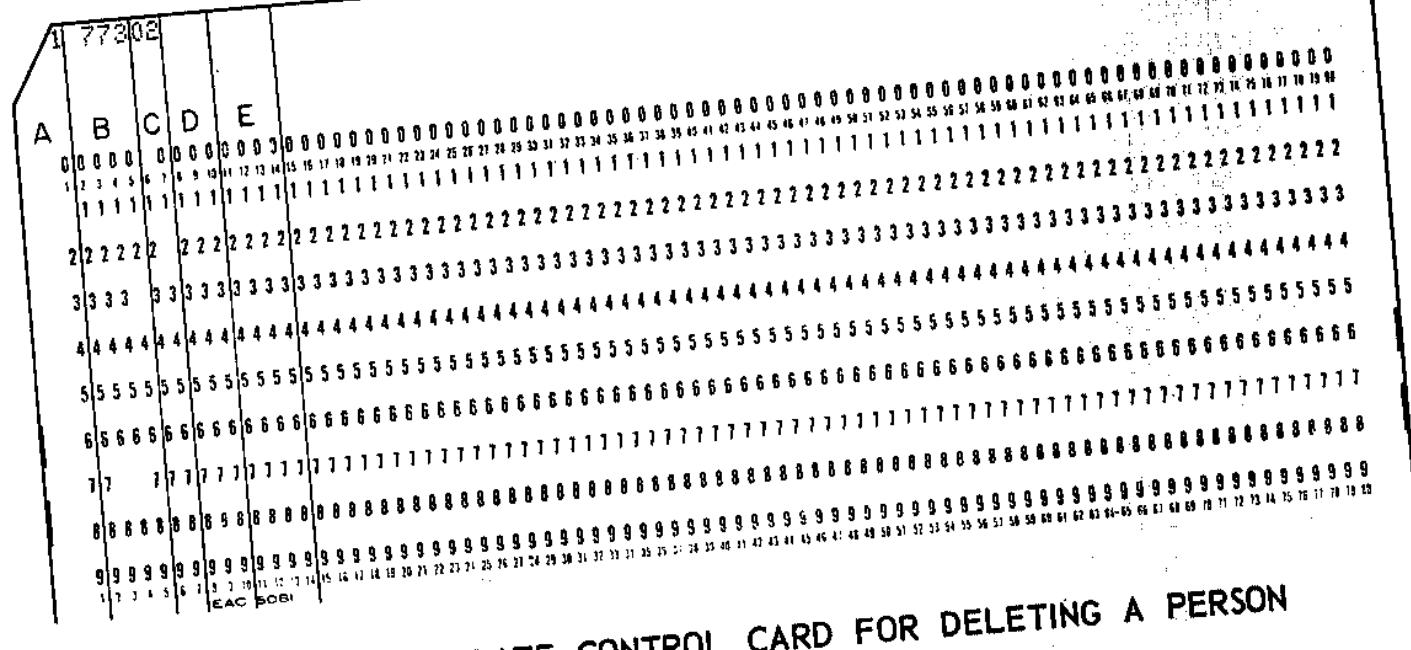

FIG. 25 UPDATE CONTROL CARD FOR DELETING A PERSON

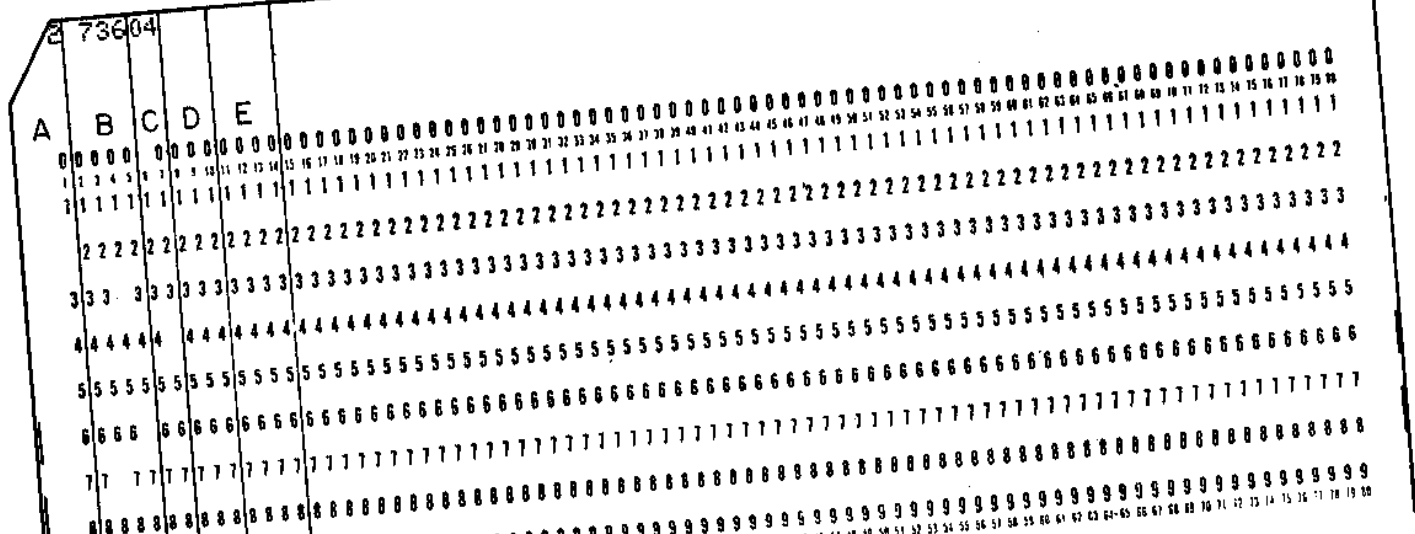

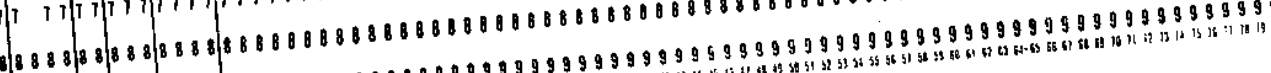

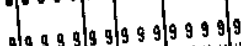

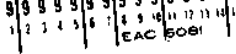

FIG. 26 UPDATE CONTROL CARD FOR DELETING A JOURNAL 


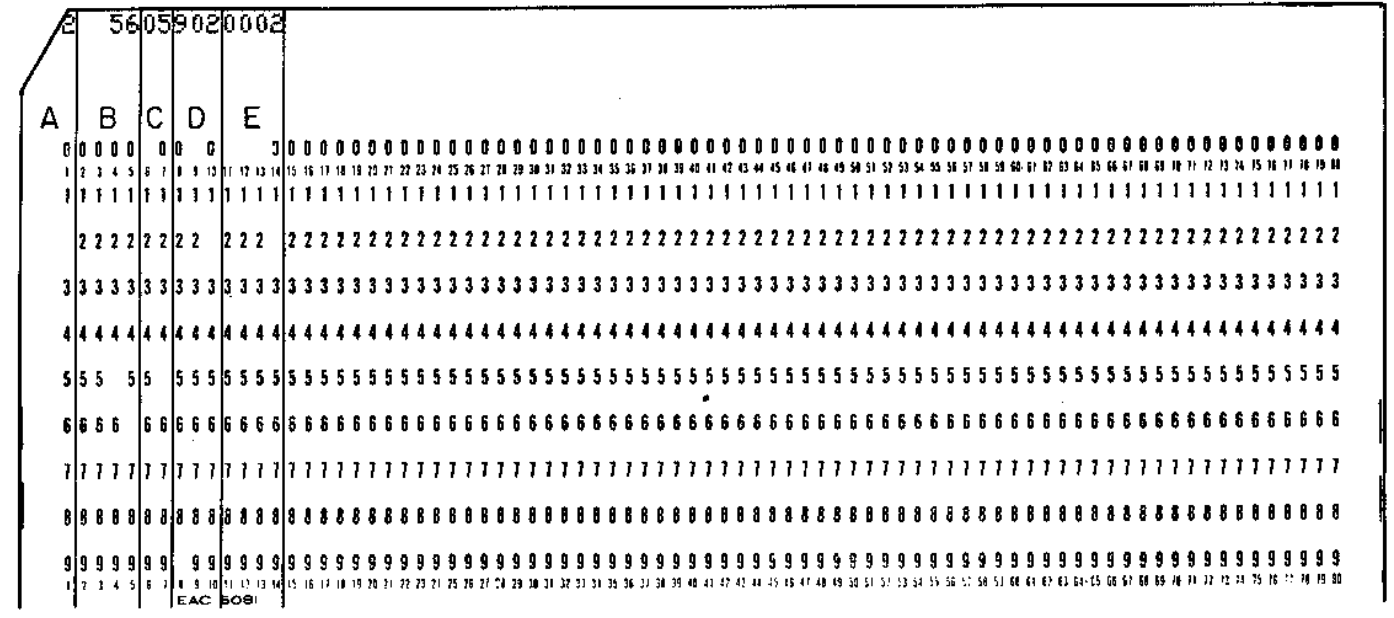

Distribution

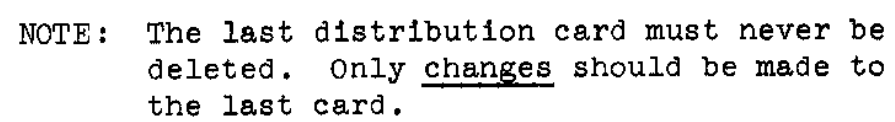

FIG. 27 UPDATE CONTROL CARD FOR DELETING A DISTRIBUTION LIST

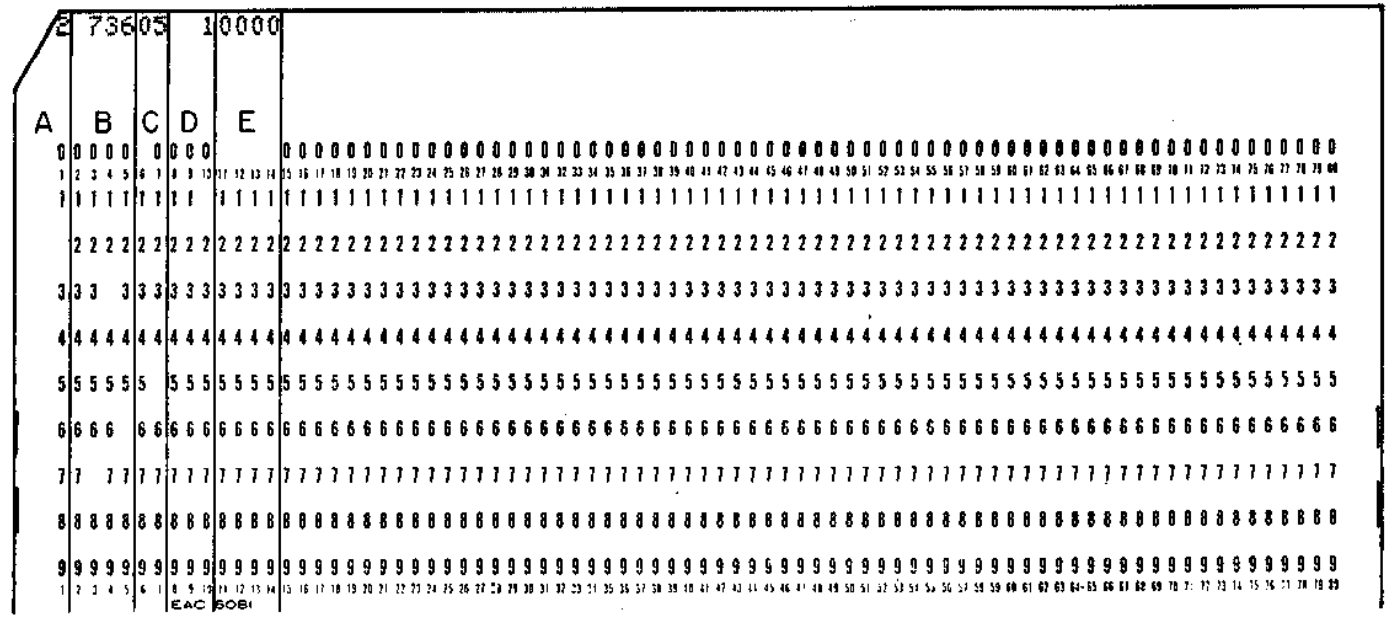

A corrected card must follow this control card. The corrected card must be in the format indicated by the number in $D$ :

$$
\begin{aligned}
& 001 \text { - Perlodical card } \\
& 002 \text { - Direct order card }
\end{aligned}
$$

003 - 008 - Information card

901 - 950 - Distribution card

FIG. 28 UPDATE CONTROL CARD FOR CHANGING JOURNAL DATA 


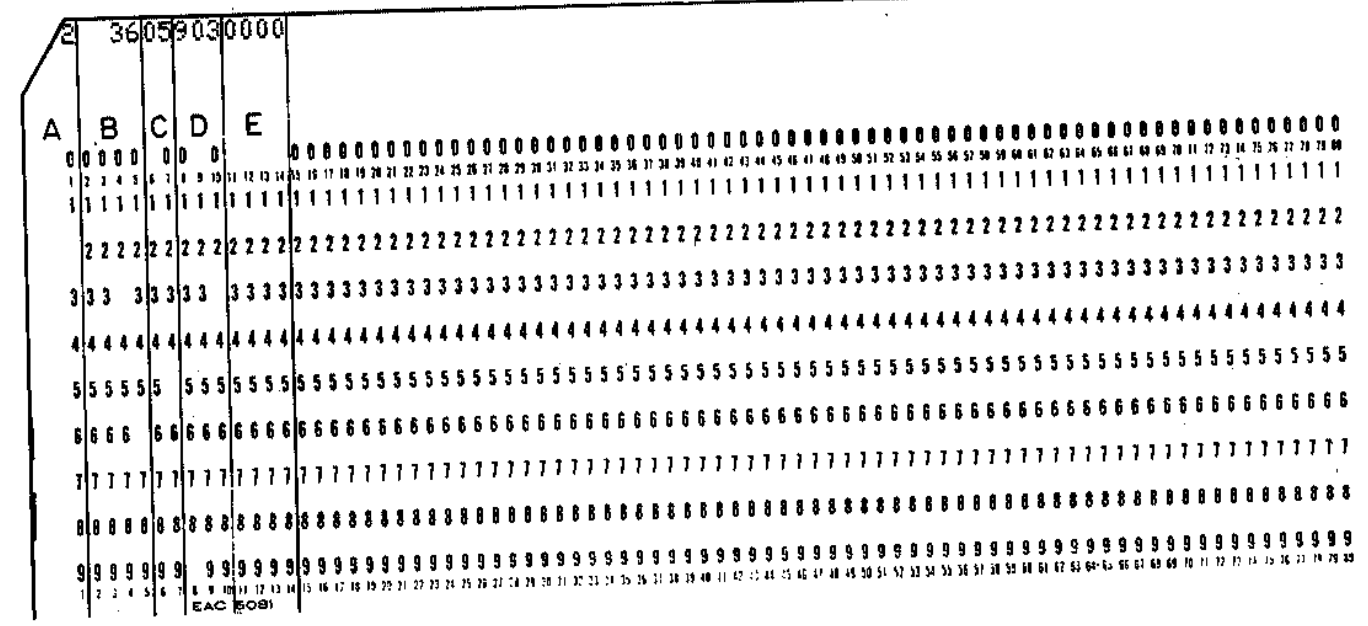

FIG. 29 UPDATE CONTROL CARD FOR CHANGING A DISTRIBUTION LIST

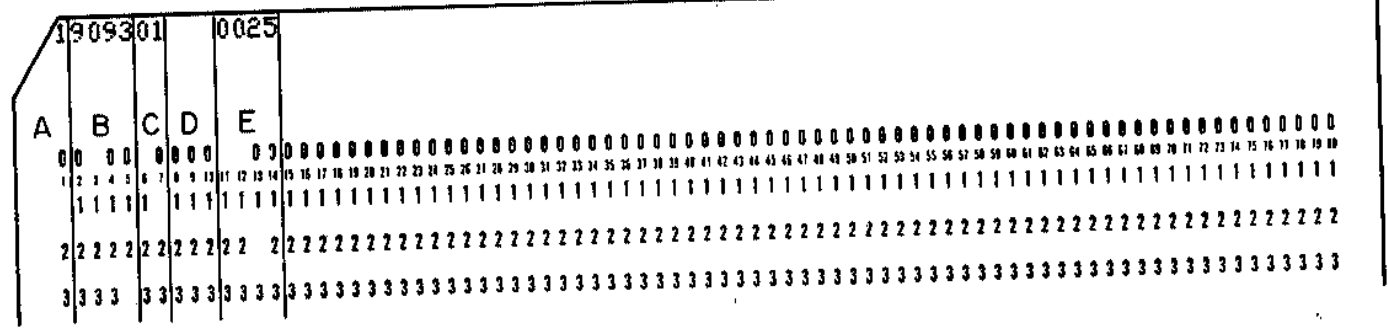

Update Control Card

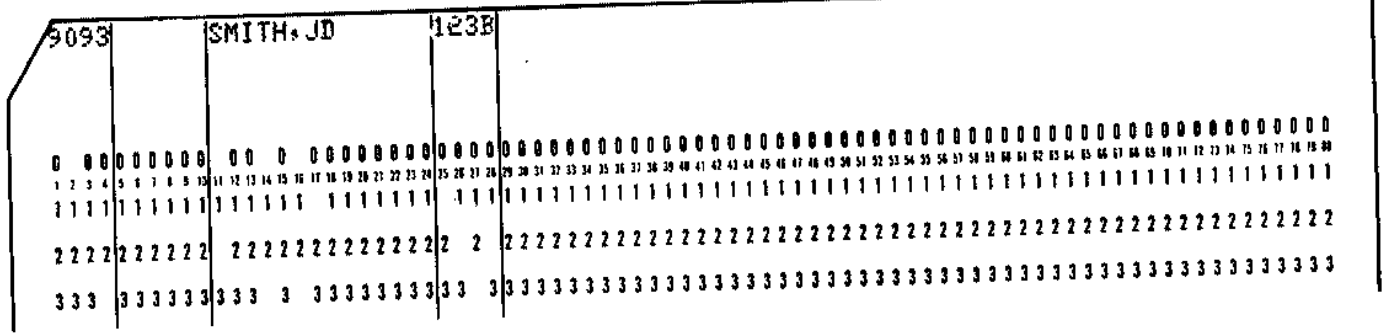

Personnel Card

FIG. 30 CARDS FOR ADDING A PERSON 

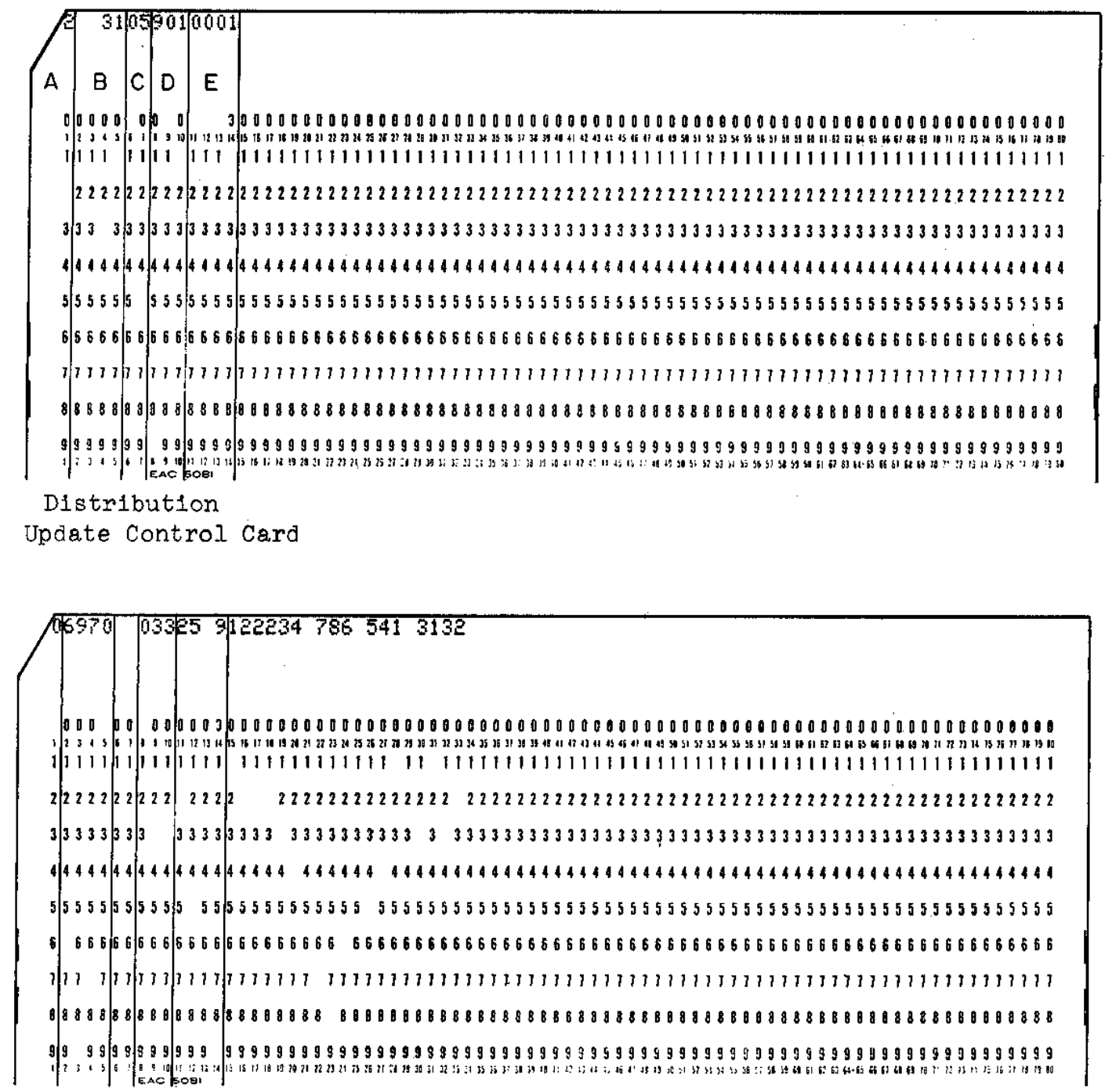

Distribution Card

FIG. 31 CARDS FOR ADDING A DISTRIBUTION LIST 


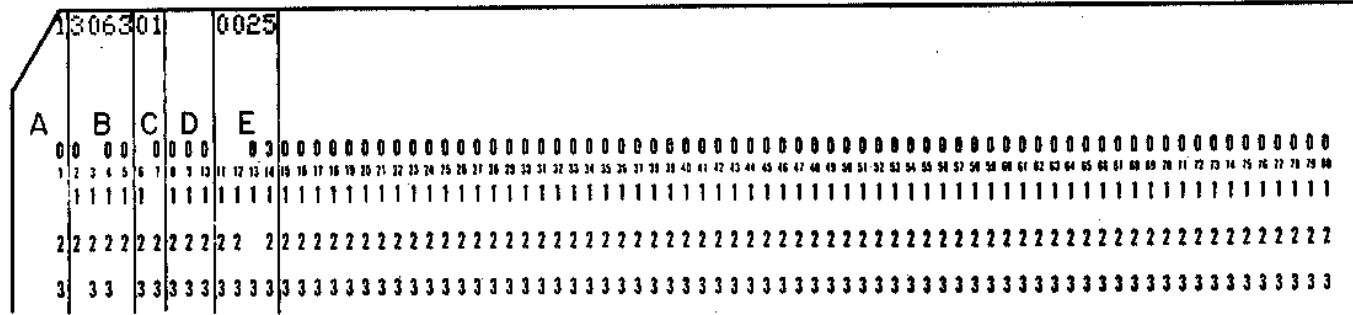

Update Control Card

to insert corrected data

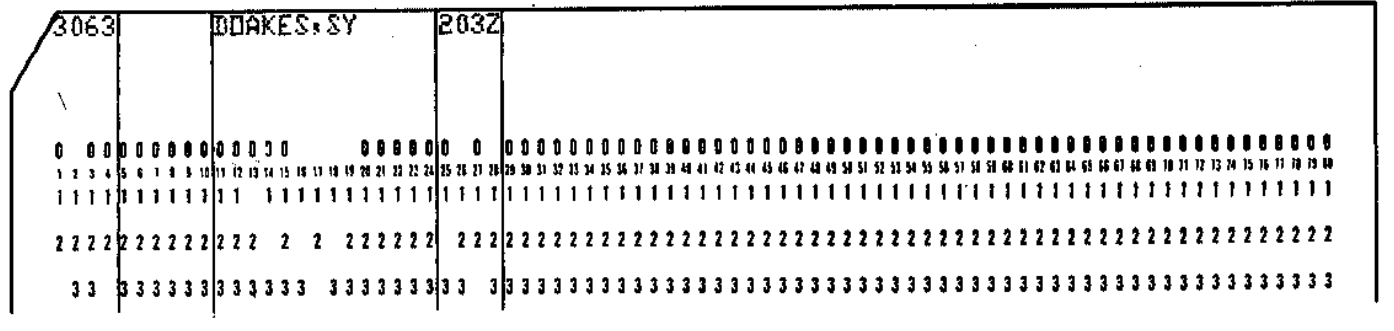

Corrected Card

Step I

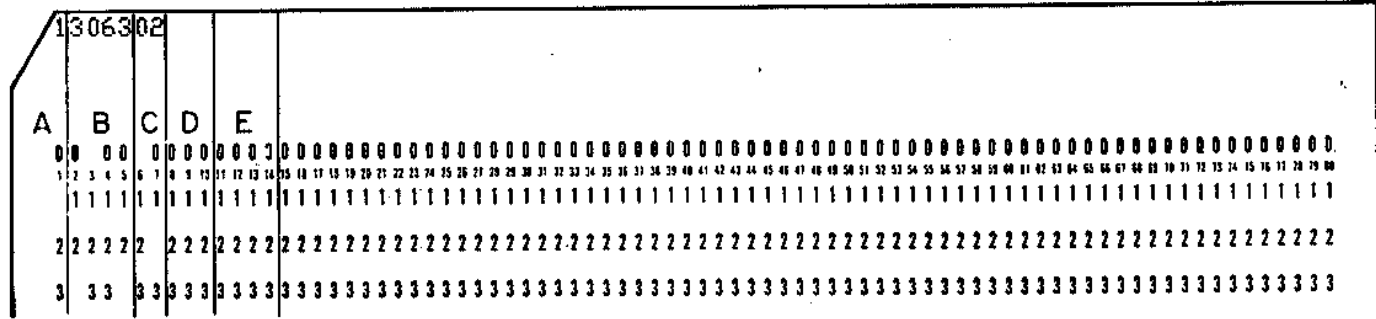

Update Control Card

to delete the incorrect data

Step II

FIG. 32 CARDS FOR CHANGING PERSONNEL DATA 


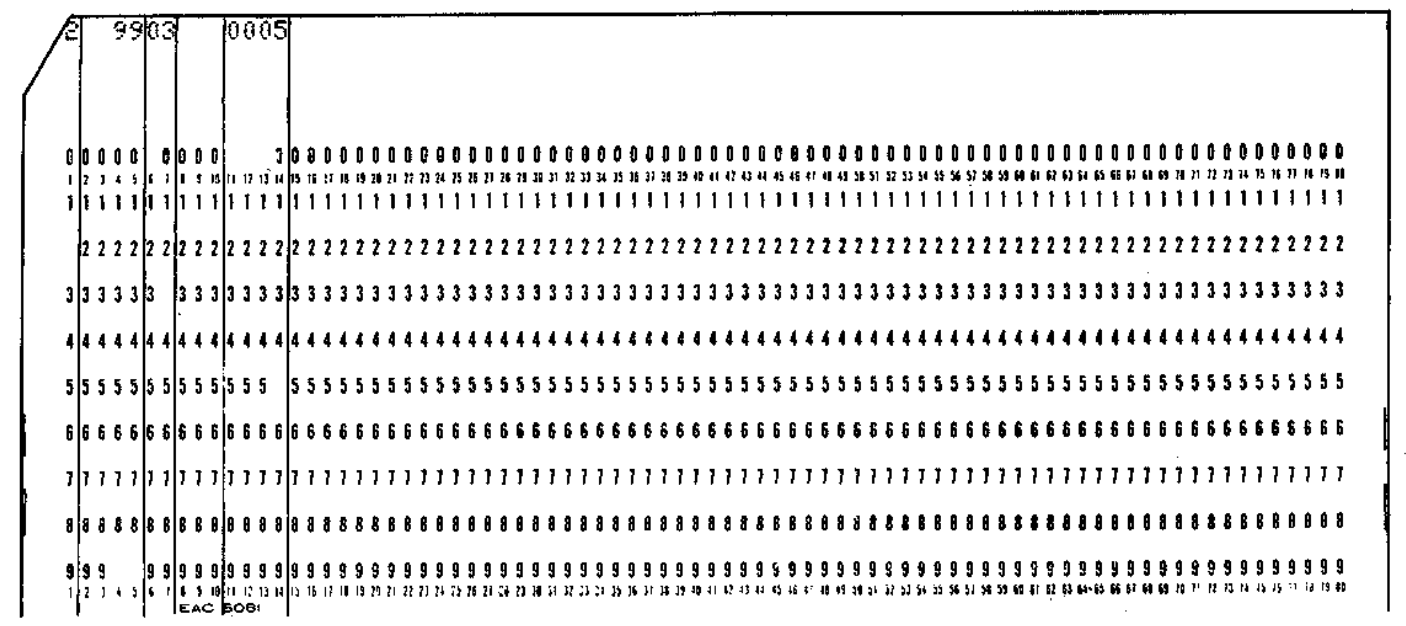

FIG. 33 UPDATE CONTROL CARD FOR ADDING A JOURNAL

The update control card must be followed by a periodical card, direct order eard if necessary, six information cards, and the distribution cards for the new journal.

\section{Output}

The circulation and renewal lists are standard for each run. The number of copies of the circulation list printed for each journal copy is related to the frequency of publication. If the journal is published weekly, five coples of each circulation list are printed for each month's run; if blweekly, two coples; if monthly, bimonthly, quarterly, or irregularly, one copy.

The renewal lists contaln the journals which should be reordered two months from each run.

The complete list of circulating and reference room coples and library holdings are printed if indicated on the master control card. The list of journals circulated to each person is also optional. 